\title{
La Vita beati Iohannis pii patriarche Alexandrie (BHL 4392): editio princeps y traducción
}

\author{
Olga Soledad Bohdziewicz / Inés Warburg \\ Universidad de Buenos Aires-IIBICRIT-CONICET / Universidad de Buenos Aires-CONICET \\ soledad.bohdziewicz@,conicet.gov.ar \\ https://orcid.org/OOOO-OOO2-7234-4377 \\ ineswarburg@hotmail.com \\ https://orcid.org/OOOO-OOO2-4360-5275
}

Received: I3/O5/202I; accepted IO/O7/2O2I

DOI: $\underline{\text { https://doi.org/IO.7203/MCLM.8.20900 }}$

The Vita beati Iohannis pii patriarche Alexandrie (BHL 4392): editio princeps and translation

Abstract

This paper offers the editio princeps of the life of John the Almsgiver transmited in ms. Paris, Bibliothèque nationale de France, Lat. 3820 . This codex dating from the I 4 th century belonged to the St. Trophime cathedral of Arles. It is the only known witness of a late translation of the saint's life written by Leontius of Neapolis, already spread across the latin world trough the version of Anastasius the Librarian. A concise introduction to the latin text and a Castilian translation are presented alongside the critical edition.

KEYWORDS

Leontius of Neapolis; John the Almsgiver; hagiography; medieval Latin; medieval translation; rewriting

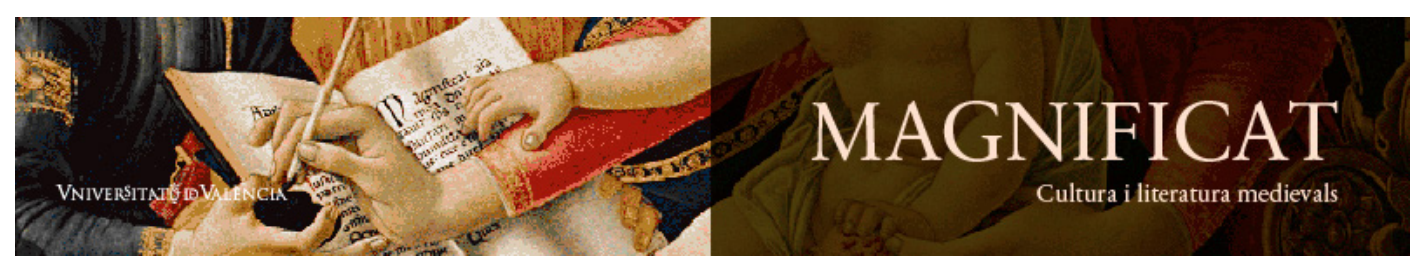

Magnificat Cultura i Literatura Medievals 8, 202I, 303-342. http://ojs.uv.es/index.php/MCLM

ISSN $2386-8295$ 
RESUMEN

En este artículo se presenta la editio princeps de la vida de Juan el Limosnero, transmitida en el ms. Paris, Bibliothèque nationale de France, Lat. 3820. Datado en el siglo XIV, este códice proveniente de la catedral de San Trófimo de Arlés constituye el único testimonio conocido de una traducción tardía de la vida del santo de Leoncio de Neápolis, ya difundida en el mundo latino a través de la versión de Anastasio el Bibliotecario. La edición está acompañada de una sucinta introducción y una traducción al castellano.

Leoncio de Neápolis; Juan el Limosnero; hagiografía; latín medieval; traducción medieval; reescritura

Olga Soledad Bohdziewicz e Inés Warburg. 202I. 'La Vita beati Iohannis pü patriarche Alexandrie (BHL4392): editio princepsy traducción', Magnificat CulturaiLiteratura Medievals, 8: 303-342, DOI: https://doi.org/IO.7203/MCLM.8.20900 G(c) Br

\section{TABLA DE CONTENIDOS}

I Introducción - 305

I.I Criterios de la edición - 307

2. Interprete anonymo Vita beati Iohannis eleemosynarius homiliario arlatense conscripta -308

2.I Apparatus criticus - 323

2.2 Locibiblici - 323

3. Vida de Juan el Limosnero compuesta por un traductor anónimo en un homiliario de Arlés -323

4. Obras citadas - 34I

5 Apéndice: Correspondencias de los capítulos - 342 


\section{ə*⿻丷木}

\section{Introducción}

De entro del complejo repertorio textual de las uitae de Juan el Limosnero, la Vita beati Iohannis pii patriarche Alexandrie del homiliario-legendario de San Trófimo de Arlés (alias San Esteban) constituye una versión singular de la leyenda en época tardía, cuyo único testimonio subsiste en el ms. Paris, Bibliothèque nationale de France, Lat. 3820 ( olim Colbert 152; Regius 3596²) (Thomas I988: 397-4I3; BHL 4392). El códice data de la segunda mitad del siglo XIV, y estaba especialmente destinado a la liturgia de San Trófimo, como revela el santoral propiamente arlesiano, próximo al del misal del ms. Lat. 875 y al del breviario del ms. Lat. $75^{2}$ para el culto de la misma iglesia en el siglo XIV.

La sucesión de los textos del manuscrito corresponde a los oficios de la parte estival del Propio, desde el 23 de junio hasta el 2I de diciembre (ff. I-2I9va), y del Común de los santos (ff. 2Igva$227 \mathrm{vb})$. Como distintivo de la liturgia local, en la sección de la fiesta de Esteban del 3 de agosto (f. 39rb), hay un reenvío extraordinario para la celebración in principio libri (principio de la parte de invierno) del natalicio del Santo patrono el 26 de diciembre. En coincidencia con la Iglesia de Oriente, que conmemora el natalicio del Patriarca de Alejandría (c. 6IO-I9) el II de noviembre, y a diferencia del Martirologio romano, que lo recuerda por la traslación del 23 de noviembre, el homiliario-legendario de Arlés coloca la fiesta del Santo en la sección de noviembre, entre las lecciones de Martín de Tours (II de noviembre) y de Bricio de Tours (ı3 de noviembre) (AASS I863: IO8-48).

Por la combinación de escritos patrísticos y leyendas hagiográficas, el ms. Lat. 3820 está clasificado como "Homiliarum-legendarium", pero existe cierta organización en lecciones para el oficio de uso secular, a semejanza del "Lectionarium" en sentido estricto (Thomas I988: IX; Dolbeau I980: I94). La Vida de Juan el Limosnero (ff. I66vb-I75ra), sin divisiones internas, aparece dispuesta para una sola lectura corrida y lleva por lema "lectio prima" entre el incipit y la capital inicial del texto. El texto está ordenado en dos columnas con la escritura característica del sudeste de Francia.

La copiosa variedad de vitae de tradición oriental y occidental, redactadas en griego, sirio, árabe, georgiano y latín (Déroche 1995: 37-48), tiene por modelo la obra que Leoncio, obispo de Neápolis en Chipre (c. 590-650), compuso en el año 64I-42 a partir de la primitiva narración de Juan Mosco y Sofronio, discípulos de Juan el Limosnero (Gelzer ed. I893; Festugière-Ryden ed. I974; Cavallero et al. ed. 20II). De la Vida de Juan de Leoncio, cuya tipología no martirial del santo resulta una peculiaridad en la hagiografía de la primera edad bizantina (Chiesa ed. 1995: 9), hay diferentes versiones denominadas según su extensión "larga", "mediana”, "corta” y "mixta” y, asimismo, hay numerosos testimonios de cada versión. Aunque el modelo griego preciso de las tres traducciones latinas conocidas no ha sido identificado, es posible advertir que son independientes entre sí, tanto por los modelos griegos de base como por el proceso de traducción de cada texto en lengua latina.

En el ámbito latino, la Vida de Juan se difundió rápidamente a partir de la traducción de Anastasio el Bibliotecario (c.858-62), dedicada ad dominum Nicolaum papam, en el marco de un ambicioso proyecto de recepción de la hagiografía no martirial griega. De la uita traducida por Anastasio (BHL 4388-439I) fueron identificados I8 manuscritos y, en tiempos de la imprenta, prosiguió la circulación de la obra, editada por Rosweyde en I6I5, dentro del canon de las Vitae patrum (Rosweyde ed. I6I5: I78-205; Chiesa et al. 2005: 89-9I). Esta traducción reproduce la 
versión corta, que también en griego es la más difundida, mediante una técnica de considerable fidelidad respecto del texto de partida (Déroche 1995: 73-75).

Circunscripta a la comunidad amalfitana del siglo XI, la segunda traducción latina en orden cronológico, conservada en el manuscrito de Nápoles ex Vindobonensis lat. I5 (olim Wien lat. 739), refleja el interés por la hagiografía oriental en ámbito napolitano (Chiesa ed. 1995: 5-8). En relación con el modelo griego, posiblemente un testimonio no identificado de la versión larga, el traductor modifica el texto con gran libertad, notable en la selección de los pasajes traducidos, permitiendo entrever las preocupaciones mercantiles de la comunidad a la cual estaba destinado el códice del monasterio de San Severino (Chiesa ed. 1995: 23-4).

Al margen de la tradición textual, las uitae de Arlés y de Nápoles comparten el criterio laxo de traducción respecto del modelo griego, la estrecha difusión con motivaciones exclusivamente locales manifiesta en los testimonios únicos para cada texto, y, por cuanto es posible conjeturar, también la remisión a la denominada versión larga de Leoncio de Neápolis, la cual precedió cronológicamente a las restantes y es la más cercana a la redacción original (Déroche 1995: 49-6I). Aunque los indicios en la traducción de Nápoles son más numerosos, la referencia del capítulo io a "la miel de segunda", mel secundo, presente también en el manuscrito de Arlés, parece suficiente para constatar que ambas traducciones proceden de la versión larga (Déroche I995:42).

La reciente edición de la versión siríaca de la vida del santo (Venturini ed. 2020) aporta nuevos elementos para considerar algunos aspectos de la rama de la tradición a la que se remonta el modelo subyacente de la traducción latina representada por el manuscrito arlatense. Una cantidad importante de innovaciones comunes, entre las que se cuenta la reorganización de capítulos y ciertas lecturas que no se comparten con otras ramas, permiten pensar en un origen común para ambas traducciones. Un ejemplo, de los múltiples aducidos por Venturini, es el capítulo 8 de la versión griega larga, relativo al armador de barcos que pide auxilio a Juan. La traducción latina y la siríaca muestran una reformulación que no se presenta en ninguna rama griega, donde se prescinde del pasaje en el que Leoncio interpela al lector para traer nuevamente en escena al santo (Venturini 20I7: 8I-82).

Al comparar las traducciones latinas con las versiones griegas, Déroche señala una serie de características distintivas de la uita del homiliario-legendario de Arlés. En primer lugar, el traductor compone un capítulo inicial, completamente distinto del modelo griego, con el que introduce una vida "plus canonique à partir du texte de Léontios". En ella se construye una breve descripción de la juventud de Juan el Limosnero, se incluye la historia del primer acto de caridad extraída del capítulo 6 , se reconstruye su carrera eclesiástica con información de los capítulos i 6,46 y 47, y se trazan las circunstancias de la elección de Juan para el patriarcado. Los 29 capítulos siguientes se suceden en un orden arbitrario respecto del modelo. Una interrupción inexplicable que deja el final del texto, correspondiente al capítulo i2 de la versión larga, inconcluso, parece indicar que el modelo estaba mutilado (Déroche 1995: 42).

Aunque la condición trunca de la narración -sea porque el texto a partir del cual se efectuaba la traducción fuera defectuoso o porque lo fuera el modelo del cual lo toma el copista del homiliariolegendario- no permite alcanzar conclusiones definitivas, en el ordenamiento de los capítulos de la versión larga -de los cuales incluye el i al IO, I8 a 26, 3O, 3I, 34, 37, 39, 43 y 49- se advierte la intención de otorgarle a la narración una mayor coherencia cronológica. Recordemos que Leoncio presenta su hagiografía como deudora y a la vez continuadora de la de Mosco y Sofronio. La pérdida de esta última, que se conoce indirectamente por estas referencias del obispo chipriota y la paráfrasis de la versión anónima y de Metafraste (Déroche 1995: 75-78), impide saber con certeza el tratamiento de la vida del santo y su incidencia en la redactada por Leoncio. Este texto condiciona la escritura de Leoncio y justifica, además, la adopción de un tratamiento no 
estrictamente sintagmático que ya daría por cumplido por la obra de sus predecesores. Así, Leoncio, en su prólogo con el consabido tópico de falsa modestia, declara que es su intención recoger otros aspectos de la vida del santo que sus anteriores biógrafos, en la obligación de dar lugar a lo más importante, necesariamente omitieron, y que él pondrá por escrito por su valor modélico una gran cantidad de episodios o anécdotas que no implican una sucesión en el plano cronológico o que, en todo caso, muestran una débil conexión con éste, puesto que el interés gravita ya en el carácter modélico del protagonista, ya en el de otros episodios donde su intervención es secundaria pero funcional al propósito edificante de la obra.

Como hemos apuntado, el primer capítulo de la versión latina transmitida en el manuscrito arlatense, con elementos estereotípicos y detalles entresacados de varios capítulos, es una innovación que pareciera estar destinada a conferir a la uita una linealidad ausente en el texto de Leoncio. Ello también se advierte en el nuevo ordenamiento de la materia, apreciable en particular por anteponer el capítulo 6 , referido a la juventud de Juan, por sobre los primeros tres capítulos. Pero, por fuera de la parte inicial, necesaria en la medida en que la reelaboración del texto buscó suprimir las instancias con fuerte presencia del autor tales como el prólogo, las referencias a las fuentes y estilo de la composición, ciertamente es difícil advertir cuál pudo haber sido el criterio aplicado en la reorganización de los capítulos. Cabe observar, no obstante, que los episodios sobre el monje castrado (capítulo 23) y el de Vitalio (capítulo 37 [38]) aparecen consecutivamente, aunque la traducción incluye otros capítulos que se encuentran entre ellos (vid. Apéndice). Pero a diferencia de los capítulos 23 y 37 [38], que poseen en común la presencia de monjes aparentemente de vida escandalosa que luego se revelan libres de pecado, los demás capítulos carecen de una trabazón temática o secuenciación cronológica clara.

En esta versión de la vida del patriarca alejandrino que nos ofrece el manuscrito de Arlés se evidencian, por cierto, las mutaciones de la tradición hagiográfica a través del tiempo. En los siglos que la separan de su contexto original de escritura, en la que el autor se presenta como testigo ocular y fiador de la veracidad de los hechos narrados, la vida del santo se reescribe adaptándose a un nuevo público, en el que sobre la figura histórica se prioriza el modelo cristiano intemporal. La riqueza de elementos relativos al imperio bizantino del siglo vII que hallamos en el texto de Leoncio, en la que se da cuenta de la organización política y eclesiástica, las controversias doctrinales y los demás aspectos de la personalidad de Juan, entre otras muchas cosas, se desvanece para centrarse en la virtud de la caridad que encarna el santo. Así se explica el escaso interés narrativo en personajes históricos, que intervienen muchas veces de manera innominada, la pérdida de detalles que sitúan con gran precisión los sitios y circunstancias en las que transcurrieron los hechos, ya que no importa tanto conservar la memoria de su administración al frente del patriarcado de Alejandría cuanto resaltar la actitud cristiana de la misericordia ante el problema de la pobreza.

\section{I.I Criterios de la edición}

Hemos respetado las formas gráficas presentes en el manuscrito, pero normalizando la frecuente separación de prefijos y radicales, como en in signis / insignis. Para una mejor comprensión del texto hemos empleado los criterios actuales en cuanto a la puntuación y uso de mayúsculas. Las abreviaturas que se emplean en el aparato crítico son las siguientes: ms. (manuscriptum), cancell. (cancellauit), s. l. (supra lineam), corr. (correxit), add. (addidit), iter. (iterauit), in ras. (in rasura), in rubr. (in rubrica). Las citas bíblicas se consignan en un aparato en la edición y también a través de notas a pie en la traducción castellana a efectos de facilitar su identificación al lector. La división en capítulos, cuyas correspondencias con las versiones griegas y otras versiones latinas se indican en el apéndice, es nuestra. 


\section{Interprete anonymo Vita beati Iohannis eleemosynarius homiliario arlatense conscripta}

[I] ${ }^{\mathrm{I}}$ Antiquorum patrum sanctorumque confessorum temporibus dum florerent fides et karitatis feruor in cordibus fidelium, | fuit in Cypro insula adolescens quidam insignis yndolis, Iohannes, cognomento pius, re et nomine Deo et hominibus gratiosus. ${ }^{2} Q u i$ sacris imbutus licteris, sanctorum patrum uitas et gesta studiose perscrutans, eorum insistebat documentis seseque moribus formabat et exemplis, potissimum autem in sui ipsius humilitate et deiectione et miserorum compassione. ${ }^{3}$ Intantum enim misericordie operibus insistebat, singulis paciens, et pro uiribus et copia sui largiens, ut cognomento misericors ab omnibus non immerito uocaretur.

[2] ${ }^{~} \mathrm{Nam}$ cum in sancte prouectionis sue primordiis adhuc agens in Cypro circiter quindecim adolescentie bone gereret annos, nocte quadam meditatione sancta delectatus, sopori se dedit. ${ }^{2}$ Cui in sompnis apparuit iuuencula speciosissima, sole lucidior et alias omnes decore precellens, habens in capite suo corona de ramis et floribus oliuarum, pulsatoque latere dormientis, excitauit eum. ${ }^{3}$ Qui statim, ea uisa, cognouit ipsam non esse de iuuenculis mundi. ${ }^{4}$ Factoque crucis signo quesiuit quenam esset et quo pacto ad eum hora et statu huiusmodi intrare presumpsisset. ${ }^{5}$ Que respondit: ${ }^{6}$ «Ego sum suppremi Regis primogenita et inter omnes alias familiarissima. $7 \mathrm{Nam}$ ego ipsa de celis ad terram eum feci descendere et genus humanum a perdictione liberare». ${ }^{8}$ Et hiis dictis, disparuit. ${ }^{9}$ Qui statim ad cor rediens, cognouit ipsam esse misericordiam, utpote coronatam oliua.

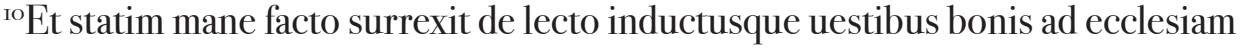
properans, obuium habuit pauperem quendam extraneum fere nudum et miseria frigoris eiulantem. "'Qui una de tunicis extracta, dedit illi, recogitans si forte in hoc perpendere posset, utrum a Deo nocturna uisio | processisset. ${ }^{22}$ Et inde procedens, paululum antequam ad ecclesiam peruenisset, obuium habuit quendam alium canum et decorum niueis uestimentis indutum, porrigentem sibi loculum cum centum bisantiis et dicentem: ${ }^{13}{ }_{3}$ Accipe et, prout uolueris, expende». ${ }^{\mathrm{I}}$ Quibus receptis, cum gaudio preteriit, sed statim retro respiciens, neminem uidit. ${ }^{5} \mathrm{Ob}$ hoc igitur gratias agens Deo, extunc se et sua operibus misericordie exposuit. ${ }^{16}$ Confessus est autem postea se multociens temptasse et probasse utrum Dominus centuplum redderet largienti, in quo etiam se peccasse professus est, et ultra non debere temptari Dominum altissimum. ${ }^{17}$ Sic igitur uir sanctus humilis et misericors ultra modum humanum effectus Omnipotenti se et sua largissime exponebat, et semper amplius atque amplius habundabat, et quod ualde mirandum nec monachatum suscipiens in sancto coniugio aliquandiu uixit in Cypro, nec tamen quouis monacho aut clerico sanctitate minor erat, sed cunctis in sancta conuersatione mirabiliter precellebat.

[3] 'Procedente autem tempore, solutus ab uxore, factus clericus, audita sanctorum patrum in Egypto et desertis adiacentibus Deo famulantum sanctitate et conuersatione mirabili Alexandriam se contulit, ibique piis insistens et pollens operibus diutius habitauit. ${ }^{2}$ Demum uero urbis illius patriarcha defuncto, prouisione diuina ab omnibus in patriarcham assumptus est, ut lucerna mirabilis poneretur super candelabrum. 3Iamque eo in sede patriarchali collocato, quantus et qualis fuerit cunctis innotuit, nam umquam in hospitio seu aula patriarchali, eo presente et cum bonorum sociorum suorum copia conferente, aliquis de secularibus negociis sermonem intermiscere presumebat, sed solum | de hiis que ad cultum Dei et opera misericordie et animarum salutem 
pertinebant. ${ }^{4}$ Multo plus etiam dum in ecclesia pro diuinus officiis celebrandis morabantur, nulli super aliis fabulari licebat, sed psalmis et orationibus insistere oportebat, et si quid forte aliud attemptaret ibidem, statim de ecclesia pellebatur.

[4] ' ${ }^{\mathrm{V}}$ nde aliquando contigit quod ciues Alexandrini, lecto euuangelio misse ad confabulandum exire de ecclesia consueti, eo presente, iuxta morem exierunt. ${ }^{2} \mathrm{Quo}$ comperto, uir Dei post eos exiens, mirantibus illis inter confabulatores sacris indutus resedit. ${ }^{3}$ Ipsisque super hoc stupentibus dixit: « Pastorem a grege non oportet separari. 5Ideoque uobiscum intrare et egredi uolo. ${ }^{6}$ Nam in capella mea missam poteram celebrare, sed ut tanti beneficii socios uos haberem, ad ecclesiam hanc descendi». "Quo audito simul cum eo intrauerunt, et deinceps egredi nisi expletis officiis nullatenus presumpserunt.

[5] 'Litibus autem et causis dirimendis pro pace suorum conseruanda certis horis et diebus uacabat, ceteris in Dei laudibus, predicatione et contemplatione et aliis necessitatibus die noctuque totaliter occupatus. ${ }^{2}$ Sed cum aliquando comperisset per hostiarios suos pauperes ad ipsum intrare non permissos, constituit duobus in eddomada diebus, quarta uidelicet et sexta feria in publico ante ecclesiam platee egredi, ibique iurgiorum materias penitus extirpare. ${ }^{3}$ Aliquantis autem in hoc diebus expletis ad tantam conciues reduxit concordiam ut quadam die de more exiens et ad lites dirimendas horarum quinque spacio residens nemo ad litigandum coram eo comparuit. ${ }^{4}$ Super quo contristatus grauiter, estimans suam esse uel fuisse negligentiam aut defectum, | recessit [f. 16zvb] plorans. ${ }^{5}$ Suis ergo intra domum familiaribus super eius mesticia conquerentibus, respondit: ${ }^{6}$ «Iohannes miser nichil hodie ad bonum laborauit». 7 Illi autem econtra: ${ }^{8}$ «Quin pocius gaudendum est tibi, pater, quod populum tuum ad tantam concordiam reduxisti, ut non iam humanam sed pocius angelicam sectentur unitatem et pacem?» ${ }^{9}$ Super quo gratias agens Deo consolationem recepit.

[6] 'Post hec sollicitus piissimus pater ne populus suus mercatorum et uendentium uersuciis fraudaretur, precepit sibi afferri pondera ciuitatis et mensuras, eisque omnibus ad equalitatem redactis, mandauit ut deinceps non mutarentur a quocumque posuitque generale edictum in tabulis descriptum super portas et muros et in plateis ciuitatis ne quisquam de cetero mensuras aut pondera presumeret in ciuitate, quia scriptum est: ${ }^{2} \ll$ Mensura et mensura, pondus et pondus abhominabilia sunt apud Deum». ${ }^{3} \mathrm{Et}$ quicumque secus attemptauerit, diripientur bona sua distribuenda pauperibus nec in hoc aliquid elemosine perciperet.

[7] 'Post hec intellexit uir Dei quod rectores ecclesiarum a subdictis suis recipiebant munera eisque conuocatis blande eos arguens ostendebat quam detestabiles sunt in scripturis sacris munerum acceptores. ${ }^{2}$ Sed ne forte excusarent se propter penuriam constituit eis duplum in pensionibus ecclesiasticis contestans eos grauiter ne de cetero quacumque occasione reciperent munera. 3Illisque annuentibus et ab huiusmodi abstinentibus ceperunt eorum beneficia crescere intantum ut infra tempus modicum reuertentes ad pium pastorem et patronum sponte resignarent et redderent quod ab eo acceperant duplum. 
[8] ${ }^{\mathrm{N}}$ Nunc iam ad eius compassionem inestimabilem opera misericordie pro parte retexenda | reuertamur. ${ }^{2}$ Collocatus igitur in sede patriarchali uenerandus antistes, conuocatis familiaribus suis inquit: ${ }^{3}$ «Circuite ciuitatem et dominos ac fratres nostros sollicite perscrutantes, describite uniuersos». ${ }^{4}$ Illis autem non intelligentibus, sed inter se querentibus quos uocaret dominos respondit: ${ }^{5}$ «Quorum est regnum celorum et qui postquam defecerimus, si amicos fecerimus, recipere nos possunt in eterna tabernacula». ${ }^{6}$ Intelligentes igitur quid diceret, circuierunt ciuitatem pauperes et inopes sollicite describendo. ${ }^{7}$ Fuitque descriptorum numerus octo milia quingenti. ${ }^{8}$ Quibus omnibus precepit de bonis suis et facultatibus ecclesie ministrare. ${ }^{9} \mathrm{Nec}$ incredibile alicui uideatur qualiter tot et tantis ministrare sufficeret, cum illis temporibus Alexandrini essent ditissimi, adeo ut aureos et argenteos non numerarent, sed appenderent magnis ponderibus et mensuris. ${ }^{\circ} \mathrm{Et}$ cum esset sancti patriarche fama celeberrima quod nichil ultra uictum pauperem sibi retinebat, sed quecumque ad manus suas ueniebant pauperibus erogabat nec alicui petenti se denegabat, omnes ei tot offerebant et tanta quod thesaurus ecclesie nunquam apud eum uisus est minui, sed pocius habundare sicut gesta eius sequentia manifeste declarant.

[9] 'Peruenit autem quodam tempore ad noticiam patricii qui regalibus negociis preerat largitas patriarche et munerum eius atque elemosinarum inestimabilis magnitudo ut quasi fons indeficiens thesauri eius scaturirent et uelud canalia inexhaustibilia deriuarentur ad pauperes. ${ }^{2}$ Qui uenit ad eum petens ex parte regis ut de tantis copiis quas sic indiscrete et ultra modum effundebat, regi subueniret. ${ }^{3}$ Quod uir sanctus audiens | aure quasi surda pertransiit, caute tamen respondit dicens: ${ }^{4}$ «Iniquum est ut thesauri regis celestis ad regis terreni manus transferantur, propter quod scias quod de bonis pauperum pictam tibi non dabo. ${ }^{5}$ Et ecce thesaurus Christi ad pedes lectuli mei rapere poteris et auferre, non a nobis sponte recipere». ${ }^{6}$ Tunc patricius uocatis satellitibus suis omnia asportauit, solum talentum unum auri relinquens, quod quintarium dicitur apud eos. 7Descendentibus autem illis per gradus aule patriarchalis obuios habuerunt quosdam ascendentes per gradus uenientes de Affrica portantes singuli super humeros amphoras auro plenas desuper sic inscriptas. ${ }^{8}$ In prima uidelicet scriptum erat «ecce mel primum», in secunda «ecce mel secundum», et in aliis «ecce mel sine fumo». ${ }^{9}$ Que cum uidisset et legisset patricius, remandauit patriarche sibi de melle illo portionem reseruare. ${ }^{r o}$ Tunc patriarcha presentatis sibi amphoris descripsit cartam patricio presentandam in hec uerba: ${ }^{"} \ll$ Scias, fili patrici, quod non mentitur qui dixit suis "ego non te deseram neque derelinquam". ${ }^{2} V$ nde certissime scias quod nullus mortalium potest thesauros immortalis regis exhaurire, propter quod tibi mittimus partem mellis huius». ${ }^{\text {r3Patricius }}$ igitur, recepta carta cum amphora, aperiens eam inuenit aurum intus. ${ }^{\mathrm{I}} \mathrm{E}$ t perlecta carta uiri sancti in qua continebatur "scias in omnibus aliis amphoris mel huic simile contineri», cum festinatione ad uirum Dei rediit, uno solo secum assumpto, omnibus que asportauerat reportatis, additis insuper de suo tribus aliis quintariis. ${ }^{15} \mathrm{Et}$ procidens ad pedes eius, sibi petiit indulgeri, quod non ex se sed ex consilio malignorum fecerat, offerens etiam penam quam uellet ei imponere super hoc se fac $\mid$ turum. ${ }^{16}$ Quo audito patriarcha miratus est humilitatem suam et confortans eum uerbis dulcibus remisit, et receptis eis que attulerat, recepit eum deinceps in amicicia et familiaritate magna.

[Io] 'Accidit autem quadam die dominica ut, descendente uiro Dei ad ecclesiam, occurreret ei quidam de conciuibus diues et catholicus, sed ipsa nocte a latronibus 
spoliatus. ${ }^{2}$ Narratoque infortunio quod sibi acciderit, uir sanctus camerarium suum uocauit precipiens ut quindecim auri pondera, que uulgo rote dicuntur, donaret eidem. ${ }^{3}$ Camerarius autem, inito consilio cum yconomo ecclesie, dedit spoliato solum quinque rotas. ${ }^{4}$ Reuertente igitur uiro dei ab ecclesia, occurrit ei uidua quedam unicum habens filium, offerens ei loculum quinque auri talenta que uulgo quintaria dicuntur continentem, et dicens: ${ }^{5}$ «Hoc munus ecclesie offero». ${ }^{6}$ Acceptoque munere ueniens patriarcha ad cameram suam uocauit camerarium suum querens ab eo quantum homini priori contulisset. ${ }^{7}$ Qui respondit: ${ }^{8}$ «Quantum uestra sanctitas imperauit». ${ }^{9} \mathrm{Et}$ cognoscens in spiritu uir Dei camerarium fuisse mentitum, uocari fecit spoliatum adiurans eum ut uere diceret quantum a camerario recepisset. ${ }^{\circ} Q$ Qui dixit: ${ }^{\mathrm{I}} \ll$ Quinque rotas». ${ }^{12}$ Et increpans camerarium ait: ${ }^{13}$ «Ecce repetet a nobis Dominus decem quintaria que cum aliis quinque uidua mulier attulisset, si huic spoliato dedissetis quantum mea nobis paternitas imperauit». ${ }^{\mathrm{I}} \mathrm{Et}$ uolens hoc probare uocauit eam ad se, mandans ei ut certificaret eos quantum ecclesie dare disposuerat. ${ }^{5}$ Que ueniens et residuum afferens narrauit quod ipsa in carta quadam descripserat se daturam quintaria quindecim, sed per horam unam in oratione persistens cartam rursus explicauit et subductis decem I quinque tantum in ea reperit. ${ }^{16}$ Et dixit: ${ }^{17} \ll$ Per memetipsam forsan non placet Deo ut plus hac uice largiar. ${ }^{{ }^{8}}$ Ideoque retentis decem quinque solum attuli». ${ }^{19}$ Recedente autem uidua ceciderunt ad pedes eius transgressores mandati, petentes hac uice sibi misericorditer indulgeri, firmiter promittentes quod mandatum eius nullatenus de cetero preteribunt.

[II] ${ }^{~}$ Eo tempore contigit a barbaris et infidelibus depopulari finitimas regiones et multos ex christianis fugere in Egyptum et propter famam largitatis uiri sancti uenire ad eum in Alexandriam quasi ad portum salutis et locum refrigerii. ${ }^{2}$ Ipse autem recipiebat eos et fouebat uerbo et opere non quasi extraneos uel hospites, sed uelud domesticos et fratres, ponens seorsum infirmos et debiles in quodam hospitali magno quod ad receptaculum talium fecerat fabricari. ${ }^{3}$ Precipiebat autem eis ibi necessaria ministrari quousque conualescerent et sponte abirent. ${ }^{4}$ Sanis uero ab eo petentibus faciebat singulis masculis dari unam auri peciam decem nummos ponderantem que uulgo karrobolum dicitur, feminis uero singulis duas petias huiusmodi. ${ }^{5} \mathrm{Nec}$ quisquam petens etiam preter habitum et uultum penurie repellebatur ab hoc munere. ${ }^{6} \mathrm{Et}$ cum ministri eius murmurarent super aliquibus ornate indutis ad hoc uenientibus redarguit eos aspere dicens: ${ }^{\circledR}$ Dominus omnipotens qui dixit "omni petenti te tribue" noluit Iohannem miserum habere camerarios disputantes de petentibus quis egeat et quis non indigeat, sed ea que Christi sunt nostre dispensationi tradita omnibus petentibus absque murmuratione et disputatione seu protractione habundanter et hylariter impartiri pro Christo. ${ }^{8} \mathrm{Quod}$ si omnes quotquod sunt Alexandrie uenirent ad petendum, Christi thesauros exhaurire non possint | et tollerabilius esset me parcum esse erga proprios filios et parentes quam erga Christi membra et pauperes».

[I2] 'Hiis temporibus accessit ad uirum Dei quidam de Nubia olim magnus mercator in maris nauigio, sed fortuna depressus, petitoque subsidio dedit ei uir sanctus quinque auri rotas. ${ }^{2} \mathrm{Qui}$ comparatis inde mercibus oportunis naue honerata nauigare cepit. ${ }^{3} \mathrm{Et}$ turbato mari uehementer, proiectis omnibus, cum uase uacuo Alexandriam remeauit. ${ }^{4}$ Reuertensque ad sanctum patriarcham cum fletu et angustia cordis iterum eius misericordiam postulauit. ${ }^{5} \mathrm{Cui}$ sanctus patriarcha respondit: ${ }^{6} \ll \mathrm{Nisi}$ cum censu ecclesie 
censum tuum pernitiosum et fraudulentum miscuisses, passus naufragium non fuisses. ZEt statim precepit ei dari alias decem rotas auri adiurans ut nichil de censu proprio illis admisceret. ${ }^{8}$ Qui ex auro eodem emptis mercibus honerata naue rursus cepit nauigare et per unam diem a portu recedens, nimia tempestate correptus, nauem fractam totaliter simul cum mercibus perditit antedictis. Ipso cum sociis dei nutu et uirtute saluatis. ${ }^{9} \mathrm{Et}$ Alexandriam rediens ad uirum Dei regredi non audebat, sed seipsum quasi desperatus iugulare uolebat. ${ }^{\text {Io }}$ Quo comperto uir Dei in spiritu eum absque ulla hesitatione uenire precepit. "Veniens igitur cum mesticia et dolore sparsis crinibus puluere et cinere, caput et faciem aspersus, proiecit se coram eo. ${ }^{\mathrm{I}} \mathrm{Quem}$ uir sanctus aloquens blande confortabat eum dicens: ${ }^{13}$ «Noli timere quia de cetero non pacieris naufragium neque hoc hac uice passus fuisses, nisi de censu iniquo et male acquisito nauem comparasses». ${ }^{14}$ Et statim precepit ei unam de nauibus ecclesie dari honeratam frumento. ${ }^{15}$ Et tradita est ei cum uiginti milibus modiorum frumenti. ${ }^{16}$ Recedens igitur cum ea de | portu uiginti diebus et noctibus prospere nauigans ignorabat quo tenderet, nisi quod singulis noctibus uidebat uirum Dei tenentem themonem et dicentem: ${ }^{17} \ll$ Ne timeas quia bene et recte nauigas». ${ }^{18}$ Sicque cum mirabili uelocitate nauigantes applicuerunt Britaniam, ubi erat caristia maxima. ${ }^{19}$ Venientesque ad eum incole offerebant ei pro singulis modiis singulos aureos uel pro honere nostri uasis in frumento honus euisdem in stagno. ${ }^{20}$ Qui petiit de frumenti precio medietatem sibi dari in auro et medietatem in stagno. ${ }^{21}$ Quo recepto, uolens Alexandriam reuerti, medio itinere diuertit ad portum cuiusdam ciuitatis ibique descendens quandam stagni partem exposuit uenalem. ${ }^{22} \mathrm{Et}$ dato precio uoluit emptor probare stagnum, eoque in igne proiecto manifeste patuit purum esse argentum. ${ }^{23} \mathrm{Et}$ ueniens ad uenditorem increpabat eum dicens: ${ }^{24} «$ Quare temptans me maliciose fraudem imposuisti michi ut argentum pro stagno recipiens te deciperem?» ${ }^{25}$ Qui uenditor cum detestatione abnegans duxit eum ad nauem ut uideret stagnum residuum. ${ }^{26}$ Quo uiso et probato patuit totum esse argentum. ${ }^{27}$ Iurauit ergo uenditor se nescire, sed meritis sancti patriarche et uirtute eius qui aquam conuertit in uinum hoc factum fuisse. ${ }^{28}$ Super quo gratias egerunt altissimo ac sic ulterius prospere nauigantes uenerunt Alexandriam. ${ }^{29} \mathrm{Et}$ narratis omnibus que fuerant gesta sancto patriarche, optulit ei argentum memoratum. ${ }^{3 \circ}$ Qui totum respuens uniuersa cum uase ipso donauit mercatori.

[13] ${ }^{\mathrm{N}} \mathrm{Nec}$ solum eum ad tantam pietatis et misericordie excellentiam gratiam diuina prouexit, uerum multos alios per ipsum. ${ }^{2}$ Erat enim in alia ciuitate uicina episcopus quidam parcus et parum misericors nomine | Troilus. ${ }^{3}$ Qui congregatis triginta rotis auri, [f. 16gva] uenit Alexandriam ad emendum uasa aurea et argentea ex illis. «Et cum ad sanctum patriarcham uisitandi more uenisset, uir sanctus assumpto secum dicto episcopo ad suum hospitale descendit, suos uisitans imbecilles. ${ }^{5}$ Erat autem hospitale spatiosum intra curiam pergrandem una porta et custodia conclusum et multas uarias camerulas distinctum ut diuersarie secundum status uarios inbecillitatum reciperentur ibidem. ${ }^{6}$ Illis ergo uisitatis hortatus est episcopum ut compateretur eisdem. ${ }^{7}$ Qui quadam pietate motus et uerecundia donauit illis rotas antedictas et, accepta a sancto patriarcha licentia, ad hospitium suum rediens cepit penitere de facto et contristatus grauiter incidit in calorem. ${ }^{8}$ Vocatusque die altera ad mensam sancti uiri excusauit se per langorem. ${ }^{9}$ Statimque uir sanctus, comperta in spiritu causa morbi, dixit: ${ }^{10}$ «Non decet coram nobis socium nostrum pati». "Et surgens, acceptis secum rotulis auri totidem, descendit ad uisitandum egrotum. ${ }^{12} \mathrm{Et}$ subridens dixit ei: ${ }^{13}$ «Non credatis quod nos animo spoliandi uos subsidium uestrum petierimus, sed ludentes hoc diximus». ${ }^{\mathrm{I}} \mathrm{Et}$ deposito ante eum 
auro, dixit: ${ }^{15}$ «Ecce uestra sint uobis. ${ }^{16}$ Non oportet uos propter hoc dolere et egrotare». ${ }^{1-}$ Tunc episcopus in hylaritatem uersus et gaudium et refrigerium, confessus est re uera se propter hoc doluisse. ${ }^{18} \mathrm{Cui}$ sanctus respondit: ${ }^{19}$ «Hoc pacto reddidi uobis dans pauperibus totidem, ut totam michi super hoc concedentes elemosinam, licteras inde manu propria describatis». ${ }^{20}$ Qui accepto calamo scripsit: ${ }^{2}{ }$ Domine Deus omnipotens, totam domino patriarche huius helemosine concedo remunerationem». ${ }^{22}$ Surgensque abiit cum domino patri | archa. ${ }^{23} \mathrm{Et}$ sumpto cibo cum gaudio sequenti nocte uidit in sompniis palatium inestimabile de auro purissimo super cuius portam superscriptio in tabula dependebat hiis uerbis: ${ }^{24} 4$ Ecce palatium indeficientis gaudii quod episcopo Trophile propter elemosimas suas paratum est». ${ }^{25}$ Cumque apud se hec gaudens reuolueret, subito apparuit uir potens in comitatu nobili, accedensque ad portam antedictam clamauit: ${ }^{26}$ «Tabulam hanc cito deponite et hanc eius loco reponite». ${ }^{27}$ Erat autem in hac secunda talis descriptio: ${ }^{28}$ «Ecce palatium indeficientis gaudii, quod patriarcha Iohannes ab episcopo Trophila sibi comparauit». ${ }^{29} \mathrm{Hac}$ igitur uisione conturbatus euigilauit et ad uirum Dei rediens cum dolore cordis uisionem sibi exposuit. ${ }^{3}$ Et petita indulgentia confortatus est a sancto patriarcha, ostenso sibi quantum pietas prosit et elemosina. ${ }^{3}$ Sicque ad locum suum rediens episcopus deinceps factus est misericors et largus.

[I4] ${ }^{\mathrm{I}}$ Eo tempore intellexit uir sanctus quod quidam Deo deuotus Modestus nomine reparabat in Iherusalem loca sancta ab infidelibus dissipata, et uolens tanti beneficii esse particeps, misit illuc mille bisancios et mille saccos frumenti et mille saccos leguminum et mille uasa plena salsis piscibus et mille ollas plenas syrupo et mille rotas ferri et mille operarios rogans ita: ${ }^{2}$ «Indulgete quia parum misi. ${ }^{3}$ Vellem pocius illuc ire, si fieri posset, et manibus propriis laborare. ${ }^{4} \mathrm{Nec}$ propter hoc nomen meum describatis inter adiutores, sed rogate piissimum Patrem ut in libro uite describatur».

[15] ' Temporibus huius sancti patriarche erat Alexandrie unus de opulentis Petrus nomine qui misericordiam non habebat ad pauperes. ${ }^{2}$ Quadam uero die congregatis in unum et ad solem sedentibus | turbis pauperum, ceperunt inter se conferre de ciuibus misericordibus benedicentes eis et econtra aliis maledicentes. ${ }^{3}$ Tandem conuerterunt se ad dictum Petrum querentes inuicem si aliquis eorum beneficium recepisset ab eo nec inuentus est unus. ${ }^{4}$ Inter quos surrexit unus dicens: ${ }^{5}$ «Quid dabitis michi si ab ipso elemosinam obtinuero?» ${ }^{6}$ Et promiserunt se ei daturos. ${ }^{7}$ Qui procidens ad portam diuitis expectans ut ueniret, tandem uidit eum uenientem cum asinis pane honeratis et petiit ab eo elemosinam. ${ }^{8}$ Qui ad uocem pauperis motus ad iram, uertebat se huc atque illuc querens lapidem quem prohiceret in eum nec inueniebat, sed arrepto pane percussit ex eo pauperem in facie ictu magno. 9 Pauper uero panem recolligens, uenit ad socios suos dicens et iurans: ${ }^{\mathrm{I0}}$ «Ecce panis quem statim de manu Petri recepi». "Post biduum autem egrotante Petro, uidit in sompno se stantem ad iudicium, de omnibus factis suis ponderatis instantem. ${ }^{\mathrm{I}} \mathrm{S}$ ex ex una parte stabant horribiles et nigri opera eius mala ex quadam parte cumulantes in lance et ex altera parte candidi et decori querentes quid contra ponerent nec inueniebant sed dolebant. ${ }^{{ }^{13}}$ Tandem unus ex eis inquit: ${ }^{{ }^{14}}$ Ecce panis unus quem semel pauperi proiecit turbatus». ${ }^{15} \mathrm{Et}$ apposito pane in lance, eque cum malis omnibus ponderauit. ${ }^{16} \mathrm{Et}$ gauisi candidi dixerunt ei: ${ }^{17} \ll$ Petre, uade et satage ut iungas. ${ }^{17}$ Alioquin cedes in partem horribilium». ${ }^{18}$ Euigilans autem et uisionem aduertens dixit intra se: ${ }^{19}$ «Si panis iste malo animo datus te ad presens de potestate malorum eripuit, 
quanto magis elemosine ex misericordia et hylaritate collate». ${ }^{20} \mathrm{Et}$ ab illa die cepit pauperibus copiose compati affectu et effectu. ${ }^{21}$ Quadam die redeunte eo de ecclesia obuiauit ei ethiops quidam, qui nuper de naufragio nudus eua| serat et deposito quo superinduebatur nobili uestimento dedit ei rogans et obsecrans ut pro Deo illud indueret. ${ }^{22}$ Pauper autem erubescens eo uti abiit. ${ }^{23}$ Et dum uenderet illud in platea, Petrus uidens hoc doluit et recludens se in camera planxit dicens: «24Non eram dignus recipere uicem beneficii huius a paupere». ${ }^{25}$ Et obdormiens uidit ante se hominem pulcherrimum lucidiorem sole crucem super caput gestantem indutum uestimento predicto et dicentem: ${ }^{26} \ll$ Petre, cur fles?» ${ }^{27}$ Qui respondit: ${ }^{28} \ll$ Quia pauper uester nimis me despexit». ${ }^{29} \mathrm{Et}$ Dominus ad eum: ${ }^{30}$ «Cognoscis hoc indumentum? ${ }^{3} \mathrm{Ex}$ illa hora qua dedisti illud pauperi indui meipsum ex illo». ${ }^{32}$ Et euigilans gratias egit Deo dicens: ${ }^{33}$ «Beati pauperes, uiuit Dominus, ex quo scio quod ipsi gerunt personam Christi, nolo mori donec sim unus ex illis». ${ }^{34}$ Et statim uocans ad se unum de familiaribus suis ait: ${ }^{35}$ Secretum meum grande tibi committo, quod si cuiquam reuelaueris, uendam te barbaris. ${ }^{36}$ Accipe has decem rotas auri et eme ex eis merces quas mecum Iherosolimam deportabis uenales. ${ }^{37} \mathrm{Et}$ cum eas uendideris, me ipsum quoque ibidem alicui uendere non postpones et pretium totum pauperibus erogabis. ${ }^{38} \mathrm{Attonitus}$ autem seruus id facere recusabat, sed minis et instancia domini uictus acquieuit et iussa domini compleuit. ${ }^{39}$ Vendidit igitur dominum suum in Iherusalem cuidam amico suo precio bisantiorum triginta tradens ei et dicens: ${ }^{40}$ «Hic sclauus uir bonus est et benedictus et multiplicabuntur bona uestra a Deo per eum. ${ }^{4} \mathrm{Et}$ hec dicens ualedicens domino suo recessit promittens se precium pauperibus pro Christo daturum et nemini hoc reuelaturum. ${ }^{42}$ Seruiuit igitur humiliter Petrus domino suo in omnibus indutus uilibus, ieiuniis, uigiliis et orationibus insistens, | ab aliis famulis fatuus reputatus, et illatas ab eis contumelias et uerbera pacienter ferebat. ${ }^{43 \mathrm{Et}}$ obdormiens uidebat Christum in forma supradicta indutum uestem eius predictam et in manu sua tenentem precium uenditionis eius et dicentem: ${ }^{44}$ «Petre frater, noli contristari. ${ }^{45}$ Ecce precium tuum quod accepi, pacienter age et sustine, donec tempus ueniat ut tua iusticia reueletur». ${ }^{4}$ Dominus autem eius mirabatur humilitatem eius, pacientiam et labores. ${ }^{4} \mathrm{Et}$ quia Dominus omnipotens benedixerat domini sue propter illum, multociens eum manumisisset si ille consensisset. ${ }^{4}$ Procedente autem tempore uenerunt ab Alexandria campsores Iherosolimam. ${ }^{49}$ Quos dominus Petri ad conuiuium inuitauit. ${ }^{50}$ Sedentibus autem illis in mensa, uiderunt Petrum seruientem eis et murmurabant inter se dicentes: ${ }^{5}$ «Nonne iste est Petrus Alexandrie prepositus?» ${ }^{2}$ Petrus autem hoc perpendens ab eorum se conspectibus occultabat. 53Illi autem domino dicebant: ${ }_{54}$ «Magnus est iste sclauus uester et de maioribus terre nostre». ${ }^{55}$ Quidam autem ex eis tercio Petrum diligenter attendens dixit: ${ }^{56}$ «Vere iste est Petrus. ${ }^{57}$ Surgam et tenebo eum, quia rex noster ualde dolet et sollicitus est super eo». ${ }^{58}$ Quod Petrus audiens, deposita quam gestabat scutella secessit ad portam. ${ }^{59}$ Ianitor autem surdus erat et mutus a natiuitate. ${ }^{60} \mathrm{Cui}$ nutibus et signis familia loquebatur. ${ }^{6 \mathrm{~A}}$ Accelerans autem Petrus dixit ei: ${ }^{62}$ «In nomine Ihesu Christi aperi michi, frater». ${ }^{6}{ }_{3} \mathrm{Ad}$ cuius uocem aperte sunt aures eius, et lingua eius soluta. ${ }^{6}$ Et respondens ait: ${ }^{6}{ }$ «Libenter pater mi». ${ }^{66} \mathrm{Et}$ statim aperiens portam emisit eum et abiit. ${ }^{6}$ Ianitor autem surdus conscendens et exclamans ad dominum dixit: ${ }^{68}$ «Domine Domine, ille qui in coquina seruiebat, exiit. ${ }^{69}$ Videte ne fugiat a uobis quia homo sanctus est et famulus Dei, quia | dum me adiuraret ut aperirem, uidi ex ore eius uerba prodeuncia uelud flammam ignis, que cum tangerent aures meas et linguam, statim reserata sunt omnia. ${ }^{70}$ Tunc surrexerunt omnes sequentes eum et non 
inuenientes reuersi sunt gratias agentes Deo et penitentiam agentes qui in eum peccauerant et qui audierunt hec, glorificauerunt Deum. ${ }^{\mathrm{r}} \mathrm{A}$ Amen.

[I6] 'Quadam autem die legente sancto patriarcha uitas patrum occurrit ei mirabile de sancto Serapione misericordie et largitatis exemplum. ${ }^{2} \mathrm{Nam}$ cum pauper quidem peteret elemosinam ab eo nec pre manibus ei aliquid dandum occurreret, extractam qua induebatur tunicam porrexit pauperi. ${ }^{3}$ Et paulo post occurrit ei alius similiter petens suffragium. ${ }^{4}$ Qui rursus extracta ea que sola supererat camisia pauperi tribuit et, omni proiecta uerecundia, pro Christo nudus remansit solo in manibus suis relicto Euangelii libro. ${ }^{5}$ Veniens autem ad suos et interrogatus ab eis quis eum spoliasset, aperto Euuangelii libro quem tenebat, respondit: ${ }^{6}$ «Iste qui hoc dixit et scribi uoluit: "omni petenti te tribue"». ${ }^{2}$ Et rursum aliis petentibus cum nichil haberet nisi solum Euuangelium, uendidit illud et dedit pauperibus. ${ }^{8} \mathrm{Et}$ cum clericus suus quereret quid de libro Euangelii fecisset, respondit: ${ }^{9}$ «Ille qui dixit "si uis perfectus esse, uade et uende omnia que habes et da pauperibus, et habebis thesaurum in celo" me illud sibi uendere compulit et suis precium dare». ${ }^{\circ}$ Hoc igitur perlecto fleuit et conuocans clericos suos ait: I" Ecce quam bonum est sanctorum gesta reuoluere». ${ }^{\mathrm{I}}$ Certe credebam me facere pro Christo distribuendo pauperibus ea que michi et ecclesie largiebantur a piis fidelibus, sed non audieram eorum largitatem qui totaliter se denudabant et propria sua corpora uendebant ut darent pauperibus. ${ }^{33}$ Exinde amplius exarsit homo Dei in operibus | pietatis.

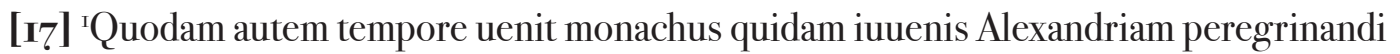
causa et orandi ad memoriam beati Cirilli. ${ }^{2}$ Et circumducens secum per ciuitatem quamdam iuuenculam speciosam petebat elemosinam et scandalizabantur in eis plurimi. 3Tandem accusatus apud sanctum patriarcham precepit eos capi et separatim carceri mancipari. ${ }^{4}$ Ministri autem excedentes uiliter tractauerunt monachum et uerberauerunt grauiter. ${ }^{5}$ Nocte autem in sompniis apparuit monachus santo patriarche et ostendit ei dorsum suum dicens: ${ }^{6}$ «Numquid placent uobis, pater, hec flagella? ${ }^{7}$ Scitote quod grauis est in hoc facto negligentia uestra et culpa». ${ }^{8}$ Et hiis dictis disparuit. ${ }^{9}$ Mane uero fecit

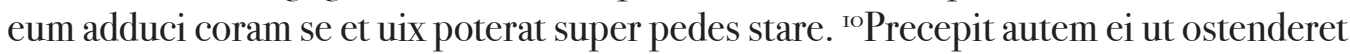
dorsum suum et corpus ut probaret quod uiderat. "Et precepit pudenda eius circumcingi panniculo ut plenius eum inspiceret. ${ }^{\mathrm{I} 2}$ Sed uolente Domino cecidit subito panniculus et apparuit manifeste eunuchus et castratus, sed non apparebat exterius propter iuuentutem. ${ }^{13}$ Et uidens uulnera dorsi eius uocauit eos qui hec fecerant et, amotis eis ab officiis suis, ipsos per triennium a sacra communione suspendit. ${ }^{14}$ Excusans autem se quod eo ignorante factum fuerat, redarguit monachum dicens: ${ }^{15}$ «Valde inhonestum est talem circumducere iuuenculam cum habitu monachali, ne nomen Domini et religionis status per te blasfemetur in gentibus». ${ }^{16}$ Monachus autem cum omni humilitate cepit ei narrare quare et qualiter hoc faciebat dicens: ${ }^{17}{ }^{\circledR}$ Venienti michi peregrinandi et orandi causa Alexandriam, occurrit michi ista apud Gazaram confitens se iudeam esse et uelle baptisari. ${ }^{18}$ Ego uero timens offensam Dei si tam pium opus despicerem, assumpta ea mecum in itinere et hucusque deducta, feci eam baptisari. ${ }^{19} \mathrm{Et} \mid$ instruens eam in professione fidei cogitaui elemosinas ad opus eius colligere eamque alicubi in collegio sanctimonialium collocare. ${ }^{20} \mathrm{Nec}$ cogitabam homines posse habere suspitionem de huiusmodi castrato». ${ }^{21}$ Hiis auditis sanctus patriarcha conuertens se ad socios suos gratias agebat Deo, qui sanctos suos sic habuit reconditos. ${ }^{22}$ Et narrata uisione sua priori 
precepit eis ut darent monacho centum bisancios. ${ }^{23}$ Quos respuens monachus dixit: ${ }^{24}$ «Eos qui confidunt in Domino talibus non indigere». ${ }^{25}$ Et hiis uerbis cognouerunt amplius sanctitatem eius et genuflexo ualedicens patriarche recessit. ${ }^{26}$ Ex tunc autem amplius dilexit monachos patriarcha beatus et honorauit fecitque ad opus et receptaculum talium seorsum in hospitali suo cameras fabricari ipsisque ibidem honeste necessaria ministrari.

[18] 'Temporibus illis erat in quodam monasterio extra Alexandriam monachus quidam sexagenarius mente et opere religiosus nomine Petalius. ${ }^{2} \mathrm{Hic}$ audita fama misericordie et piorum operum patriarche beati cogitauit ad eius instar magnificum aliquid facere in oculis Dei, sed ualde pudendum in oculis hominum, uolens etiam simul cum hoc experiri si uir sanctus facile moueretur ad susurria aut pocius haberet intra se discrectionem spirituum. ${ }^{3}$ Et relicto monasterio cepit in ciuitate morari et de manuum labore uiuere. ${ }^{4}$ Omni autem die postquam stipendium diurnum a conductore suo receperat, cibum de uilissimo genere leguminum, quod uulgo lupinum dicitur, et aqua sola temperatum comeditur pro obolo uno uel picta emebat et manducabat ac de illo uiuebat. 5 De residuo autem stipendii sui diurni emebat sibi per totam noctem corpus alicuius meretricis, pactum cum ea faciens ut cum aliquo nocte illa peccare non posset. ${ }^{6}$ Sed et ipse tota nocte | morabatur apud eam obseruans ne aliquis ad peccandum intraret. ${ }^{7}$ Et uigilans pro maiori parte noctis in aliquo lupanaris angulo psallensque cum genuflexionibus crebris orabat ut Dominus omnipotens hospitam suam misericorditer respiceret et a peccato liberaret. ${ }^{8}$ Illucescente autem die commendabat eam Deo obseruans ut abstineret a peccato et adiurans eam ut nemini facta monachi et dicta reuelaret. ${ }^{9} \mathrm{Et}$ sic per diem sequentem laborans ad aliam meretricem per noctem similiter declinabat. ${ }^{\text {Io }} \mathrm{Et}$ sic diebus singulis apud singulas similia faciens circumibat. "Plurimis autem ciuibus per ciuitatem ei super hoc obloquentibus et cum dictis meretricibus de eo disputantibus contigit semel unam ex illis excusationem monachi gesta sua aliquibus reuelare. ${ }^{12}$ Quo comperto monachus eam maledixit statimque ipsa mentis alienationem incurrit. ${ }^{33}$ Plurimi autem non propter maledictionem sancti, sed plus quia propter tegendum eis flagitium mentita fuerat, hoc ei accidisse dicebant. ${ }^{\mathrm{I}}$ Nulla autem ex aliis ueritatem confiteri audebat ne consimile pateretur. ${ }^{5}$ Ipsemet autem uespere labore dimisso palam audientibus multis sibimet loquens dicebat: ${ }^{16}$ «Frater Petali, uade hac nocte deliciari cum tali que te expectat». ${ }^{17}$ Propter quod grauiter ei insultabant audientes. ${ }^{18}$ Quibus ipse respondebat: ${ }^{19}$ «Non creditis quod monachi carnale corpus gestent sicut et uos? ${ }^{20}$ Vere sciatis quod ego homo sum sicut et uos et uoluntatem humanam habeo sicut et ceteri». ${ }^{2 I}$ Illi autem contra: ${ }^{22} \ll$ Prohice habitum monachalem et duc tibi uxorem ut non propter te uituperetur nomen monachorum». ${ }^{23}$ Ipse autem dicebat: ${ }^{24}$ «Sinite me in pace. ${ }^{25}$ Numquid iudices mei estis? ${ }^{26}$ Cogitate de uobis. ${ }^{27}$ Ego uos non iudico. ${ }^{28}$ Vnus est in celo qui uos et me pariter iudicabit». | ${ }^{29}$ Tandem clerici domino patriarche suggesserunt de eo nec tamen audiebat eos, sed dicebat: ${ }^{30}$ «Quiescite a detractione monachorum. ${ }^{3 \mathrm{I}}$ Mementote quid fecerit egregius imperator Constantinus, qui Nicena sinodo cartulas omnes ad detractionem et uituperium monachorum conscriptas et sibi in publicum presentatas gremio suo colligens in ignem coram cunctis proiecit dicens: ${ }^{32}$ "Si propriis oculis uiderem eos peccare, mantellum meum apponerem eos operiens ne uiderentur ab hominibus". ${ }^{33}$ Vos autem contra hoc facitis. ${ }^{34}$ Mementote quid alias perpetrastis in alium iuuenem monachum circumducentem iuuenculam in quem me peccare fecistis. ${ }^{35}$ Monachus autem in statu predicto morabatur rogans Deum ut parceret male sentientibus de eo et 
obloquentibus ei. ${ }^{6}$ Et multe de predictis mulieribus ad exortationem et exemplum eius reliquentes prostibula penitentiam egerunt quedam maritate, quedam sanctimonialium societatem ingresse. ${ }^{37}$ Quadam autem die exeunte monacho hospicium principalioris inter meretrices occurrit ei unus de lenonibus et eleuans manum dedit alapam monacho dicens: ${ }^{30}$ «Senex uilissime, quam diu uitam hanc duces turpissimam?» ${ }^{39}$ Ad quem monachus: ${ }^{40}$ «Vere scias, miser, quod sic percutieris in breui ut ciues Alexandrini stupefacti conueniant ad uidendum». ${ }^{4}$ Habebat autem monachus camerulam ad portam ciuitatis orientalem prope ecclesiam, in qua conueniebant ad eum muliercule ibique post multas exortationes et labores obdormiuit in Domino. ${ }^{42}$ Eadem hora uenit ad predictum lenonem quidam teterrimus et percutiens cum ictu magno proiecit in terram. ${ }^{43} \mathrm{Qui}$ postea surgens cucurrit ad cameram scissa ueste clamans culpam suam et petens misericordiam. ${ }^{44} \mathrm{Appropinquante} \mathrm{|} \mathrm{eo} \mathrm{hostium,} \mathrm{occurrit} \mathrm{ei} \mathrm{demon} \mathrm{in} \mathrm{terram} \mathrm{deiciens} \mathrm{et}$ suffocans ipsum. ${ }^{45}$ Populus autem secutus circumdabat pacientem. ${ }^{6} \mathrm{Ex}$ quibus unus intrans cameram defuncti inuenit corpus eius super genua et uidit in pauimento camere descriptum: ${ }^{47}$ «Homines Alexandrini, nolite quemquam ante tempus iudicare quoadusque ueniat qui illuminabit abscondita tenebrarum». ${ }^{4}$ Exeunte autem eodem de camera aliosque uidenda ad hec uocante, dimisit demon flagellatum. ${ }^{49}$ Qui coram cunctis flens et penitens enarrauit qualiter sanctum Dei percusserat et que ab eo audierat. ${ }^{\circ} \mathrm{Post}$ hec currens ad patriarcham beatum, singula ei per ordinem nunciauit. ${ }^{5} \mathrm{Qui}$ consurgens, ordinata processione clericorum, uenit ad cameram lectisque licteris pauimenti gratias egit Deo dicens coram cunctis: ${ }^{2} \ll$ Per Dei gratiam euasi ego miser pestilentiam huius flagellati quam fere incurri». ${ }^{53}$ Tunc conuenerunt mulieres omnes per sanctum monachum a peccato liberate flentes et omnibus ueritatem uite eius edicentes, asserentes pro certo quod eum super latus dormire non uiderant nec solam manum alicuius carum tangere aut uinum semel bibere. ${ }^{54}$ Et cum increparentur a cunctis quod tantas sancti uirtutes tacuerant, excusabant se partim eius inhibitio et precepto, partim exemplo percusse mulieris a Domino. ${ }^{55}$ Igitur eleuantes sanctum corpus et ad ecclesiam deportantes cum magno sepelierunt honore. ${ }^{6}$ Homo autem ille, qui flagellatus fuerat, annis multis solemnitatem beati monachi in expensis magnis et elemosinis faciebat. 57 Tandem monasterium eius ingrediens et propriam magistri sui cameram inhabitans uitam finiuit in pace. ${ }^{58}$ Sanctus autem patriarcha Deo gratias agebat quod in monachum sanctum non peccauerat. ${ }^{59}$ Sed et ciues Alexandrie extunc a iudiciis hominum et detractionibus monachorum cepe | runt abstinere. ${ }^{6 \circ}$ Multa autem per eum miracula fecit Deus post mortem ipsius.

[19] 'Quid autem de humilitate huius sancti patriarche congrue dici poterit cum inter alios omnes non solum uerbo sed et habitu et gestu humillimus appareret? ${ }^{2}$ Vnde contigit eum semel a quodam amico suo diuite intra cameram patriarchalem uisitari, a quo sanctus patriarcha consueuerat ad opus pauperum accipere quod uolebat. ${ }^{3}$ Visaque humilitate grabati in quo iacebat et humili quo tegebatur opertorio, reuertens domum diues ille misit ei opertorium satis pulchrum dicens: ${ }^{4}$ «Recipiat uestra sancta paternitas hoc munusculum et amore mei utimini illo ad tegumentum uestrum et lectuli uestri, quia non decet patriarchale cubile sic uilescere». ${ }^{5}$ Recepto igitur munere operuit se illo nocte una, sed redarguente conscientia cepit litigare secum dicens: ${ }^{6}$ «Quot et quanti fratres Christi rigescunt frigore stridentes dentibus? ?Quot sunt qui natam uix habent ad inuoluendum se? ${ }^{8}$ Quot etiam sunt qui pedes extendere nequeunt propter breuitatem strati et opertuli? ${ }^{9} \mathrm{Et}$ tu, miser Iohannes, iaces hic inuolutus operimento precioso, quo 
centum quadraginta quatuor Christi fratres sufficienter operiri possent». IoHoc autem dicebat, quia opertorium sibi missum triginta sex bisantios ualebat, cum per ciuitatem pro uno bisantio quatuor tapetia possent haberi. "Et confestim, mane facto, precepit illud in platea uendi coopertorium. ${ }^{\mathrm{I}}$ Superueniens autem qui miserat illud, ipsemet emit illud datisque pro eo triginta sex bisantiis, remisit illud simul cum precio rogans obnixius ut, distributo pauperibus precio, illud deinceps retineret opertulum. ${ }^{13}$ Et uocato eo ait patriarcha: ${ }^{\mathrm{I}_{4}}$ «Nunc | uidebimus quis preualebit: ego in uendendo aut tu in redimendo». ${ }^{15}$ Tunc cepit ei narrare qualiter beatus Epiphanius Ciprus peregre ueniens Iherusalem uidensque in mensa Iohanis patriarche Iherosolimitani uasa aurea et argentea, simulauit se uelle celebrare conuiuium. ${ }^{16} \mathrm{Et}$ acceptis mutuo uasis patriarche predictis, distribuit omnia pauperibus Iherosolimitis. ${ }^{17} \mathrm{Et}$ cum postea repeteret patriarcha uasa predicta, respondit ei Epiphanius: ${ }^{18}$ «Non decet Christi uicarium in huiusmodi splendide epulari et membra Christi apud eum fame cruciari. ${ }^{19}$ Propter quod pauperibus parrochianis tuis et filiis superflua tua distribuere curaui. ${ }^{20} \mathrm{Quo}$ audito, indignatus patriarcha apprehenso sancti Epiphanii uestimento superbe clamauit: ${ }^{21} \ll$ Non me trufabis taliter, sed reddes mutuata». ${ }^{22}$ Tunc humiliter respondit Epiphanius: ${ }^{23}$ «Videat Dominus quod sine causa manus temerarias in episcopum extendisti». ${ }^{24}$ Et statim aruit manus patriarche. ${ }^{25}$ Qui procidens ad pedes sancti, ueniam petiit factaque per episcopum sanctum oratione, pro eo restituta est ei manus sua. ${ }^{25} \mathrm{Nec}$ ultra usus est talibus patriarcha predictus. ${ }^{26} \mathrm{Narrauit}$ similiter eidem diuiti exemplum de quodam seruiente quem olim habuerat in Cypro dicente sibi: ${ }^{27} \ll$ Quotiens hylariter largior et habundanter pauperibus, habundant et uestra, et si quando parce, minorantur et uestra».

[20] 'Erat autem assuetus patriarcha beatus uocare ad se illos quos affluere misericordie uisceribus audiebat diligenter inquirens ab eis unde et qualiter misericordiam habuissent, utrum uidelicet a natura, sicut ille qui dicebat «ab infantia creuit mecum miseratio», an pocius ex doctrina et aliorum ammonitione et exemplo. ${ }^{2} \mathrm{Nam}$ hii qui miserationem habent innatam sicut et illi qui ceteris uirtutibus pollent ex natura tantam apud | Deum non optinent retributionem, quantam hii qui nature reluctantes se ipsos per rationem, doctrina bona et exercicio ad compatiendum et subueniendum miseris assuescunt, dicente Saluatore: ${ }^{3}$ «Regnum celorum uim patitur et uiolenti rapiunt illud». 4 Igitur inter alios inuenit uir sanctus quendam dicentem sibi: ${ }^{\circledR}$ Multo tempore duro fueram corde nec aliquid pauperibus largiebar. ${ }^{6}$ Quadam uero die audiens misericordiam et eius opera super alia commendari, reuertens ad cor, cepi michimet inferre uiolentiam et apud me statim illis, qui michi pauperes occurrerent, quinque dumtaxat quadrantes singulis

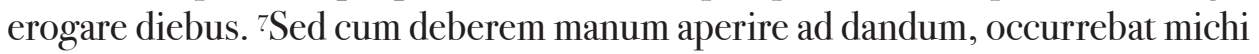
cogitatus quod ista michi et familie mee sufficeret pro leguminibus seu herbis comparandis michique uidebatur quod de ore meo et puerorum meorum hec extraherem et ideo non dabam. ${ }^{8} \mathrm{Cogitans}$ autem ne forte Deum ad iram magnam contra me prouocarem non implendo quod promiseram, precepi dispensatori meo quod dictos quinque quadrantes de meo, me ignorante, diebus singulis erogaret. ${ }^{9}$ Quod ille aliquando tempore implens, mea queque bona in manu sua plus et plus de die in diem habundare prospiciens, cepit omni die decem quadrantes, me ignorante, largiri. ${ }^{\circ} \mathrm{Cernens}$ igitur bona mea crescere propter hoc manifeste, laxauit manum et singulis diebus tres dragmas de meo, me adhuc inscio, distribuit. "Procedente autem tempore, sentiens et ego ipse tantam bonorum meorum habundantiam et incrementum, uocato famulo, decem ei precepi quadrantes distribui credens pro certo quod quinque tantum hactenus erogasset. 
${ }^{12}$ Quod audiens famulus et subridens ait: ${ }^{13}$ "Vere me latronem esse fateor, sed fidelem. ${ }^{14}$ Nam de uestro uestrum excessi mandatum, sed in utili| tatem uestra conuerti, sentiens uestra propter hoc pacienter augeri. ${ }^{5}$ Ideo plures de uestro argenteos et aureos propter Deum habundanter distribuere confisus sum et semper in hiis bona uestra crescere deprehendi". ${ }^{16}$ Per huius mei igitur seruientis industriam ad hanc pauperum compassionem et miserationes deueni». ${ }^{17} \mathrm{Hiis}$ igitur auditis, sanctus patriarcha gauisus est et agens gratias Deo se mirabile factum et Dei donum inter cetera, que legerat et audierat, nunc audisse confessus est.

[2I] ' Circa idem tempus erant Alexandrie duo clerici e uicino satis morantes, arte uiuentes sutoria. ${ }^{2}$ Quorum alter peritior arte illa minus frequentans ecclesiam operi magis intentus, uix seipsum solitarium poterat sustentare, quamquam dominicis et festiuis diebus lucri anxius aliquando laboraret. ${ }^{3}$ Alter uero minus arte peritus et plus diuinis quasi cothidie uacans officiis et frequentans ecclesiam, non modo se ipsum, sed et patrem et matrem cum uxore propria et liberis huiuscemodi artis officio sufficienter alebat et supra uicinum suum necessariis habundabat. ${ }^{4} \mathrm{Cui}$ cum alter inuidere cepisset, semel ab eo quesiuit attente unde sibi tantorum copia suppetebat, cum ipse sepius egeret, qui et peritior et magis intentus operi assidue laborabat. ${ }^{5} \mathrm{Ad}$ quem uicinus suus uolens eum ad frequentationem ecclesie allicere sic respondit: ${ }^{6}$ «Frater karissime, et ego michi aliquando sufficere non poteram, sed postquam ad Deum conuersus ecclesiam frequentare cepi, in hoc itinere michi et meis sufficienter inueni. ${ }^{7}$ Nunc ergo, si placet, meis acquiesce consiliis ut tu mecum ad ecclesiam cotidie uenias et quicquid inuenerimus inter nos equaliter diuidamus. ${ }^{8}$ Illo ergo ascendente et comparem suum ad ecclesiam sociante, ceperunt bona eius | manifeste succrescere et de die in diem amplius habundare. ${ }^{9}$ Cumque Deo et socio suo gratias agens hoc referret, ait illi socius: ${ }^{\mathrm{I}}{ }^{\mathrm{Q}}$ Vere scias, frater, quod in hoc itinere nichil umquam inueni, nisi quod a Deo prouisionis mee crementum agnoui. "Et semper illud euangelicum apud me reuolui "primum querite regnum Dei et hec omnia adicientur uobis". ${ }^{\text {r2} P o s t q u a m ~ a u t e m ~ f a c t i ~ h u i u s ~ n o t i c i a ~ a d ~}$ sanctum uirum peruenit, uocato illo qui uicinum suum ad tantum bonum allexerat, ipsum ecclesie patriarchalis ministris aggregauit, eoque proficientem in melius processu temporis presbiterum ordinauit.

[22] ${ }^{\mathrm{I}}$ Addidit etiam Dominus temptare famulum suum et probare hoc modo. ${ }^{2}$ Ingruente enim bello et manu ualida barbarorum in regiones uicinas, tanta descendit multitudo fugitiuorum pauperum fidelium in Alexandriam ad elemosinas et sustentationem uiri Dei, ut in pios illorum usus ea que apud ipsum erant in thesauris ecclesie tam in auro peccunie et argento quam etiam in frumento expenderentur uniuersa. ${ }^{3} \mathrm{Ad}$ hoc idem concurrit fames ualida, que solita Nili influentia anno illo ultra modum decurrata totam terribiliter grauauit Egyptum. 4Propter quod non solum alienigenis concurrentibus uerum etiam indigenis ad ipsum confluentibus uix sufficere poterat alimonia uiri Dei. ${ }^{5}$ Hiis igitur que apud ipsum erant deficientibus cepit ab aliis pro pauperum multitudine mendicare. ${ }^{6}$ Et cum nec ab aliis sibi data sufficerent, cepit a diuitibus mutuum accipere. zVerum cum iam auri talenta decem, que uulgo dicuntur quintaria, mutuo recepisset et nec ultra mutuum inueniret, cunctis sibi de famis inualescentia timentibus, cepit contristari et orationibus ad Deum fusis cogitare quid faceret. ${ }^{8}$ Erat autem in | ciuitate tunc diues quidam licteratus cupiens multo tempore clericus fieri et inter ecclesie ministros intitulari, sed iure prohibente non poterat, quia prima uxore sua defuncta et 
alia postmodum superducta, bigamiam contraxerat. ${ }^{9}$ Is ergo cum audisset angustias sancti uiri, cogitauit eum pecunia sua corruptum ad suum inclinare propositum. ${ }^{\text {roSed }}$ timens pre uerecundia proprio sollicitare sermone, descriptis et per filium suum missis licteris ad eum, ducentos frumenti modios cum centum octoginta rotis auri in alimoniam pauperum promisit continuo se daturum, si dispensans cum aliis suis diaconis in consortium et ministerium promoueret et reciperet leuitarum. "Allegabat siquidem quod frequenter necessitas soluit legem. ${ }^{12}$ Hiis igitur a uiro Dei perlectis licteris, uocauit eum ad se dicens ei sigillatim: ${ }^{13}$ «Oblationem tuam pro pauperum necessitate reciperemus, si eam inmaculatam habere possemus, iubente Domino hostiam omnem inmaculatam offerri. ${ }^{{ }^{14}}$ Sic enim uult sibi Dominus exhiberi gloriosam ecclesiam non habentem rugam neque maculam». ${ }^{5}$ Et addidit: ${ }^{16}$ «Numquid propter tua donaria licet nobis mutare aut corrumpere ecclesie sancte statuta? ${ }^{17}$ An non recolis illud apostolicum dictum olim offerenti pro dono celesti pecuniam? "18 "Pecunia tua -inquit- tecum sit in perditionem, quoniam existimasti donum Dei pecunia possideri”. ${ }^{9}$ Non est enim tibi pars neque sors in sermone isto. ${ }^{20}$ Cor enim tuum non est rectum coram Deo. ${ }^{21}$ Numquid inualidam putas Omnipotentis manum ut pauperibus suis prouidere non possit. ${ }^{22}$ Et qui de paucis panibus multa milia hominum saciauit, decem istos apud nos residuos frumenti modios multiplicare non poterit? ${ }^{23} \mathrm{Hiis}$ auditis, | ambitiosus ille recessit a uiro sancto cum uerecundia et rubore. ${ }^{24} \mathrm{Et}$ statim intrauit quidam cum gaudio nuncians duas ecclesie et sancti patriarche naues honeratas frumento de Sathalia et Grecie partibus aduenisse et portum intrasse. ${ }^{25}$ Tunc ait sanctus: ${ }^{26}$ «Beatus qui confidit in Domino, timens eum et mandata eius obseruans». ${ }^{27}$ Et gratias egit Deo, qui seruum suum a prauitate symoniaca seruauit incorruptum.

[23 ' ${ }^{\text {Ad }}$ uirtutem elemosine declarandam et alios ad opera misericordie inuitandos libenter referebat homo Dei miraculum quod cuidam Ciprensi aliquando contigerat hoc modo: ${ }^{2}$ «Irruentibus in Ciprum barbaris accidit quosdam Ciprenses captiuos in Persidem duci et diro carceri mancipari. ${ }^{3}$ Processu uero temporis quibusdam deffunctis aliisque redemptis ac liberatis, quidam ex eis remansit in uinculis. ${ }^{4}$ Quibusdam ergo uicinis eius ad propria reuertentibus, ceperunt parentes eius qui remanserat sollicite querere de eodem. ${ }^{5}$ Ad quos hii, qui liberati redierant, dixerunt se illum manibus suis sepelisse et hoc ita esse credebant. ${ }^{6}$ Tunc parentes inquisita et notata die mortis eius ceperunt annis singulis diebus certis pro remedio anime eius pauperibus elemosinas erogare. ${ }^{7}$ Eo igitur post quadrienium, auxiliante Domino a uinculis expedito et in Cyprum ad suos reuertente, receptus est cunctis mirantibus cum gaudio et honore. ${ }^{8} \mathrm{Cumque}$ narrarent ei quod pro deffuncto eum habentes elemosinas statutis diebus pro ipso faciebant, interrogauit eos quibus hec diebus faciebant. ${ }^{9}$ Qui dixerunt: ${ }^{10}$ "Ter in anno, die uidelicet sancto Pasche et Penthecostes ac baptisterii Dominici". "Quibus diligenter notatis ab eo, contestatus est eis quod hiis diebus ueniens ad eum in carcere uir quidam honestus albis | indutus soluensque eum a uinculis, tota die spaciando ipsum deducebat. ${ }^{\mathrm{I}} \mathrm{Die}$ uero uel nocte sequenti ipsum carceri restituens, uinculis implicabat». ${ }^{\mathrm{r}} \mathrm{H}$ Hius igitur exemplo concludebat uir Dei quam magnificum est elemosinas pauperibus impartiri, que non solum uiuis ad consolationem prosunt et requiem, sed et deffunctis ad ueniam et salutem.

[24] 'Sed ne forte fructum elemosinarum suarum quisquam in presenti constituat et expectet, ostensum est aliquando uiro Dei super hoc signum conueniens a Domino. ${ }^{2}$ Nam cum quodam tempore diues quidam Alexandrinus uidens tantam multitudinem ad 
sanctum patriarcham confluere et de bonis suis ad sustentationem pauperum in thesauros ecclesie hadundanter infundere, uenit et ipse offerens auri rotas septem et dimidiam supplicans ut rogaret Deum pro salute unigeniti sui et ad portum reduceret nauem suam quam antea miserat in Affricam. ${ }^{3}$ Asserebat etiam quod nichil auri sibi retinuerat domi. ${ }_{4}$ Recepto igitur exenio et in thesauris ecclesie subtus altare reposito, cepit orare uir sanctus pro eo et suis, ut Deus omnipotens eis concederet quod saluti animarum eorum expedire nosset. 5 Factum est igitur ut prefati diuitis unigenitus die tricesimo moreretur et die tertio sequenti uidit nauem suam uenire. 6 Sed cum deberet portum intrare, collisa subito, periit. 'Sed per Dei gratiam, submersis in profundo mercibus, homines cum ligno euaserunt. ${ }^{8}$ Sic igitur, addito infortunio ad infortunium, doluit homo ille ultra modum. ${ }^{9}$ Quibus etiam ad patriarcham delatis, compassus est et ipse homini cum dolore cordis nec tamen eum ad se uocare uoluit pre uerecundia et

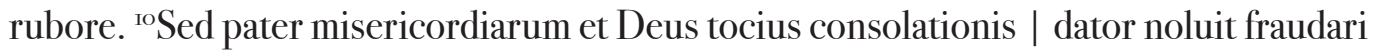
hominem a spe sua et confidentia, quam in sanctum uirum habuerat. "Nocte igitur quadam apparuit ei in sompniis homo quidam in specie et habitu patriarche dicens ei: ${ }^{12} \ll$ Quare, frater, tantum doles super morte filii tui qui assumptus est in gloria? ${ }^{\mathrm{I}} \mathrm{Et}$ si uixisset, uiam mundi ingressus periisset. ${ }^{14}$ Nonne rogasti me ut pro eius salute deprecarer? ${ }^{15}$ Et de uase, quid doles? ${ }^{16}$ Rapuit enim Dominus a te ea que aliquando tibi fuerant nocitura. ${ }^{17}$ Nonne misericordiam suam tibi ostendit qui hominum animas cum inutili censu perire non permisit? ${ }^{18} \mathrm{Hiis}$ auditis, euigilans homo surgensque mirabiliter consolatus, sanctum adiit referens ei per ordinem uniuersa que uiderat sicque inuicem mutuo confortantes gratias egerunt Altissimo.

[25] 'Post hec accidit quod uir quidam extraneus, audita largitate uiri Dei, eam uoluit experiri et induens se uiliter occurrit uiro sancto ad hospitale suum descendenti iuxta morem suum ter in ebdomada. ${ }^{2}$ Et petita ab eo elemosina, precepit uir sanctus camerario suo dare illi sex aureos. ${ }^{3}$ Et diuertens uir ille mutauit habitum rursusque occurrens uiro Dei, petiit elemosinam. ${ }^{4}$ Et precepit ei dari denuo sex aureos. ${ }^{5}$ Et cum camerarius diceret ei: ${ }^{6}$ «Agite discretius. ${ }^{7}$ Iste idem est cui dedistis sex alios aureos», uir Dei se non audisse simulauit. ${ }^{8}$ Propter quod tercio occurrit ei uir ille, mutato habitu, petens ut prius. ${ }^{9}$ Tunc uere camerarius clam impellens dominum suum digito inquit: ${ }^{\mathrm{I0}} \ll$ En truffator ille tercio reuertitur». "Exclamans autem uoce magna sanctus patriarcha dixit: ${ }^{12}$ «Nunc tercio da ei aureos duodecim, quia forte Christus est qui me temptat». ${ }^{13}$ Sic igitur recessit uir ille, probata pacientia et munifi | centia sanctissimi patriarche.

[26] 'Alia autem die exeunte beato patriarcha ad celebrandum in quadam ecclesia martyrum extra urbem, occurrit ei in itinere mulier quedam beneficium eius petens. ${ }^{2}$ Famulis autem eius dicentibus ut sustineret usque ad reditum eius increpauit eos dicens: ${ }^{3}$ «Quomodo exaudiet Dominus preces nostras, si proferamus datum angustianti?» 4Propter quod de loco pedem mouere noluit, donec fuit mulieri satisfactum.

$\left.{ }_{\mathbf{2}_{6}}\right]^{\text {E }}$ Erat in hiis diebus in urbe Alexandria iuuenis quidam bone indolis habens patrem laborantem in extremis. ${ }^{2}$ Qui dum testamentum suum faciens de bonis suis diceret filio suo: ${ }^{3}$ «uid pocius diligis de duobus, uidelicet utrum decem rotas auri quas habeo tibi legare debeam, an pocius Virgini gloriose, beate Marie?» ${ }^{4}$ Qui respondit: ${ }^{5}$ «Date pocius beate Virgini». ${ }^{6}$ Tunc precepit eas pater ad honorem beate Virginis distribui pauperibus. zDeffuncto autem patre, cepit filius egere. ${ }^{8}$ Nichilominus tamen beate Marie Virginis 
memoriam et ecclesiam die noctuque deuote frequentabat. ${ }^{9}$ Mendicare autem et auxilium ab hominibus petere erubescebat. ${ }^{\text {IoSed }}$ postquam patriarcha sanctus hec audiuit ipsumque mendicantem erubescere cognouit, uocauit quedam alium probum dicens ad eum: ${ }^{\mathrm{II}} \ll$ Describe in carta ueteri quod talis iuuenis est cognatus domini patriarche. ${ }^{\mathrm{I}} \mathrm{Et}$ quasi ea apud te reperta dices ei: ${ }^{\text {r3 }}$ "Quid est hoc quod tu pauper es cum sis cognatus tanti uiri, qui neminem ad se uenientem egere permittit? ${ }^{14}$ Nam te eius consanguineum in cartis meis repperi. ${ }^{15}$ Quod si erubescis eum alloqui, ego pro te apud ipsum intercedam"». ${ }^{16} \mathrm{Ad}$ quem iuuenis: ${ }^{17}$ «Ite, temptate et renunciate michi». ${ }^{18}$ Reuertens igitur uir ille a sancto patriarcha | narrauit iuueni responsum eius dicens: ${ }^{19}$ «Sic respondit michi homo Dei: ${ }^{20}$ "Vere scio me habere cognatum cuius non agnoui uultum. ${ }^{21}$ Sed uade et cum carta tua adduc eum ad me"». ${ }^{22}$ Adducto igitur iuuene ad sanctum patriarcham, amplexatus est eum uir beatus dicens: ${ }^{23}$ «Bene uenisti, cognate karissime!» ${ }^{24}$ Et statim data sibi copia munerum, dedit ei in coniugium filiam cuiusdam magni ciuis Alexandrini diuitis et potentis. ${ }^{25}$ Sic igitur fecit iuuenem comprobare quod nullus sperauit in Deo, qui confusus esset, sed super omnia precellit iactare in Domino cogitatum.

[28] ${ }^{\mathrm{I}}$ Eo tempore erat in partibus Alexandrie uir quidam habens casale ualde bonum, sed fructum non fecerat domino suo solitum propter siccitatem et aque penuriam. ${ }^{2}$ Et cum angustiaretur ab illis qui regalibus preerant ut censum regi debitum redderet et non haberet unde solueret, declinauit ad quendam amicum suum diuitem causa mutui contrahendi. ${ }^{3}$ Sed diues ille de die in diem mutuum differebat. ${ }^{4}$ Tandem ille necessitate compulsus regalium, indicauit sancto patriarche statum suum. ${ }^{5}$ Qui plurimum angustiato compaciens, statim concessit ei quod petebat. ${ }^{6}$ Nocte uero sequenti apparuit in sompniis predicto diuiti uisio mirabilis. ${ }^{7}$ Videbatur siquidem ei quod stabat in ecclesia inter deferentes altari munera, e quibus singuli offerentium statim recipiebant a Deo centuplum. ${ }^{8}$ Accedens autem quidam ad diuitem presentabat ei panem unum dicens:

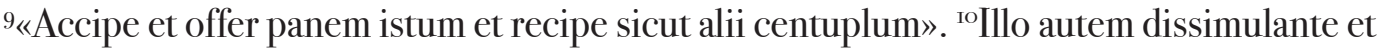
tardante, uidit sanctum patriarcham accipientem panem illum et offerentem recipientemque centuplum. "Euigilans autem et aduertens in parte uisionem fecit ad se uocari mutuantem dicens ei: ${ }^{12}$ «Vis accipere | quod petisti?» ${ }^{13}$ Qui respondit: ${ }^{\mathrm{I}} 4$ Non indigeo, quia dominus patriarcha anticipauit et fecit michi quod a te petii, quia nimium distulisti». ${ }^{15} \mathrm{Ad}$ quem diues: ${ }^{16}$ «Benedixisti, quia patriarcha bonum meum preripuit propter inerciam meam. ${ }^{17}$ Et merito, quia ue illi qui dicit amico suo "uade et reuertere cras dabo tibi cum statim possit dare" ". ${ }^{18} \mathrm{Et}$ exponens illi uisionem suam per ordinem penitentiam egit super neglicencia sua. ${ }^{19}$ Et glorificabant Deum qui iustus est et misericors in omnibus uiis suis. ${ }^{20} \mathrm{Et}$ hiis igitur et huiusmodi patet quam misericors et largus in dando fuerit uir beatus.

[29] ${ }^{\mathrm{I}}$ Sed nichilominus in condonando extitit uere misericors. ${ }^{2}$ Semel enim accidit duos ex clericis suis inter se rixari. ${ }^{3}$ Propter quod utrumque expulit ab ecclesia. ${ }^{4}$ Ex quibus unus delictum suum recognoscens penitenciam egit, et petita uenia, reconciliationem impetrauit. ${ }^{5}$ Alter uero pocius gaudebat se expulsum, ut licentius ad uana et inutilia uagaretur. ${ }^{6}$ Sed et maliciose studebat qualiter posset sanctum ad iracundiam prouocare, ita quod multi crederent ipsum patricio rapinam supradictam suggessisse. ${ }^{7}$ Cognito ergo quod propter sententiam suspentionis ab ingressu ecclesie non corrigeretur, sed pocius fieret deterior, uocauit eum ad se ut blandiciis et exhortationibus sanctis ad ecclesiam reuocaret. ${ }^{8}$ Recolebat enim uir sanctus illud apostolicum «quis infirmatur et ego non 
infirmor? » et illud «debemus nos firmiores in becillitates infirmorum supportare et non nobis placere». ${ }^{9}$ Sed nec potuit eum reuocare.

\section{I Apparatus criticus}

I I Incipit uita beati Iohannis pii patriarche Alexandrie. Lectio prima. in rubr. | et karitatis : karitatis et $m s$. | I7 atque :post a. semper cancell. ms. | | 3 I sanctitate : sancti $m s$. | 2 poneretur : ex ponetur s. l. corr. || 52 comperisset : comparisset ms. | 3 lites : lictes $m s$. || 6 I descriptum :-i-s. l. add. ms. | 2 descriptum :-i- s. l. add. ms. || 8 I compassionem : compassiones $m s$. | 8 bonis : bomis ms. || 94 regis :-s s. l. add. ms. | 7 plenas :-s s. l. add. ms. || iा I Alexandriam : Alexandria ms. I 4 peciam : peticiam ms. | 8 parentes : pereuntes $m s$. || $\mathbf{2} 6$ censu : sensu $m s . \mid 7$ censu : sensu $m s$. | admisceret : admiscet $m s$. | 8 diem : dietam $m s$. | II sparsis : spersis $m s$. || $\mathbf{I 3}_{2} \mathbf{2}$ Troilus : Trophila $m s$. | I8 sanctus : iter. $m s$. || I4 I Modestus : Modestus $m s$. | saccos : sanctos $m s$. || $\mathbf{5} 8$ facie : fatie $m s$. | 38 minis : nimis $m s$. | 48 campsores : caupsores $m s$. $\mid 55$ diligenter :-ter in ras. $\mid 67$ surdus : surdum $m s$. || I6 5 quem : quam ms. | I2 propria : ex propa s. l. corr. ms. || I7 I et : iter. $m s$. || $\mathbf{8}$ Io circumibat : circuibat ms. | 3г Nicena] uicena $m s$. | | 96 Quot: Quod ms. || 20 II incrementum : crementum $m s$. | | 223 concurrit : cum currit ms. | I4 Et addidit: iter. et cancell. $m s$. || 23 II spaciando : spaciendo $m s$. || 23 I3 salutem : Nota ne turbentur elemosinas facientes, scilicet eos infortunia grauia, ut dicitur, sequentur. Post s. in rubr. || $\mathbf{2 4}$ I 7 censu : sencu $m s$. || $\mathbf{2 6} 2$ reditum : redatum $m s . \mid 4$ satisfactum : satisfatum $m s$.

\subsection{Locibiblici}

2 I6 Dominus - largienti : cf. Matth. 19. 29, Marc. Io. 30 || $6{ }_{2}$ Mensura Deum : Prvb. 20. Iо || 7 I munerum acceptores: $c f$. Iob I5. 34 || 85 Quorum - celorum :cf.Mt.5.3 | si - tabernacula:cf. Lc. I6. 9 || 9 пा ego - derelinquam :Hebr. I3. 5 || II 7 omni - tribue :Lc. 6. 30 || I6 6 omni - tribue : Lc. 6. 30 | 9 uade - celo : $L c$. I8. 22 || $\mathbf{8} 4$ 7 nolite - tenebrarum : I Cor. 4.5 || 20 I ab - miseratio : Iob 3I. I8 | 3 Regnum - illud : Matt. II. I2 || 2I II primum -uobis :Matt. 6. 33, Lc. I2. 3I | | 22 I7 Pecunia - Deo: Act. 8. 2O-2I || 23 I4 exhiberi maculam: Eph. 5. 27 || $\mathbf{2 8}$ I7 uade - dare : Prv. 3.28 || 298 quis - infirmor : 2 Cor II. 29 | debemus - placere : Rom. I5. I

\section{Vida de Juan el Limosnero compuesta por un traductor anónimo en un homiliario de Arlés}

[I] 'En tiempos de los antiguos padres y santos confesores, cuando florecían la fe y el fervor de la caridad en los corazones de los fieles, existió en la isla de Chipre un joven de carácter notable, Juan apodado el piadoso, agradable a Dios y a los hombres de hecho y de nombre. ${ }^{2}$ Este, inspirado en las

I. Juan, patriarca de Alejandría, conocido por el sobrenombre de limosnero, había nacido en la ciudad de Amatunte y era hijo del gobernador de Chipre. Tras la muerte de su esposa e hijos inicia su carrera eclesiástica y, luego de la 
Sagradas Escrituras y examinando aplicadamente las vidas y hazañas de los santos padres, insistía en sus lecciones y se formaba en sus costumbres y ejemplos. ${ }^{3}$ Pero, sobre todo, en la humildad y en el desprecio de sí mismo y en la compasión de los necesitados. ${ }^{4}$ En efecto, insistía tanto en las obras de misericordia, paciente con cada uno y dando según sus fuerzas y capacidad, que no sin mérito todos lo llamaban con el apodo de 'misericordioso'.

[2] 'Pues, todavía en los comienzos de su santa trayectoria en Chipre, cuando tenía alrededor de quince años de buena juventud, una noche, deleitado por la santa meditación, se entregó al sueño. ${ }^{2}$ En sueños se le apareció una jovencita bellísima, más radiante que el sol y superior en elegancia a todas las demás, la cual llevaba en su cabeza una corona de ramos y flores de olivos y con un golpe en su costado, mientras dormía, lo despertó. ${ }^{3}$ Este, apenas la vio, supo que ella no era una de las jovencitas del mundo. ${ }^{4} \mathrm{Y}$ tras persignarse, le preguntó quién era y cómo se aventuraba a entrar a esa hora y de tal manera. ${ }^{5}$ Esta respondió: ${ }^{6}$ «Yo soy la primogénita del rey supremo y la más cercana entre todas las otras. 7Pues yo misma hice que él descendiera desde los cielos a la tierra y liberara al género humano de la perdición». ${ }^{8} Y$ tras decir estas palabras, desapareció. ${ }^{9}$ Este, volviendo de inmediato en sí, supo que ella era la Misericordia, visto que estaba coronada con el olivo. ${ }^{\text {IoY }}$ apenas amaneció, se levantó de la cama y, apresurándose a la iglesia, vestido con buenas prendas, encontró a un pobre extranjero, casi desnudo y en sollozos por el padecimiento del frío. "Este, tras quitarse una de las túnicas, se la dio, pues pensaba que tal vez podría evaluar con esto si la visión nocturna procedía de Dios. ${ }^{12} Y$ marchando desde allí, poco antes de llegar a la iglesia, encontró a otro, blanco y elegante, vestido con níveas prendas, que le extiende una bolsa con cien bizancios y dice: ${ }^{{ }^{3}}$ «Toma y gasta como quieras». ${ }^{14}$ Luego de tomarlos, se fue con alegría, pero, al mirar de inmediato para atrás, no vio a nadie. ${ }^{5}$ Dando, pues, gracias a Dios por esto, se ofreció desde entonces a sí mismo y sus bienes a las obras de misericordia. ${ }^{16}$ Pero confesó que después de esto muchas veces tentó y probó si el Señor le devolvía el céntuplo al que daba, " en lo cual también declaró que había pecado y que en adelante el altísimo Señor no debía ser tentado. ${ }^{r 7}$ Así pues, el santo varón, hecho humilde y misericordioso más allá de la medida humana por el Todopoderoso, se ofrecía muy generosamente a sí mismo y a sus bienes y siempre tenía más y más, y es muy admirable que antes de tomar los hábitos vivió un tiempo en Chipre en santo matrimonio y, sin embargo, no era menor en santidad a un monje o clérigo, sino que admirablemente superaba a todos en la santa vida religiosa.

[3] 'Pero pasado el tiempo, libre de su esposa, hecho clérigo, luego de haber oído acerca de la santidad y de la vida admirable de los santos padres que sirven a Dios en Egipto y en los desiertos aledaños, se trasladó a Alejandría y allí habitó por largo tiempo dedicándose y fortaleciéndose en las obras piadosas. ${ }^{2}$ Finalmente, en verdad, luego de que murió el patriarca de aquella ciudad"I por providencia divina, fue recibido por todos como patriarca, así como se coloca una lámpara admirable sobre el candelabro. ${ }^{3} \mathrm{Y}$ ya ubicado en la sede patriarcal, todos conocieron cuán grande y cómo era. Pues rara vez en el hospicio o en la sede patriarcal, estando él presente y reunido con el grupo de sus buenos compañeros, alguien osaba entremeter una conversación sobre asuntos temporales, sino solamente sobre aquellas cosas que pertenecían al culto de Dios y a las obras de misericordia y a la salvación de las almas. `Mucho más aún, cuando permanecían en la iglesia para celebrar los divinos

muerte de Teodoro en el año 6o9, asume el Patriarcado de Alejandría bajo el emperador Heraclio. En 620, habiendo abandonado Alejandría, muere en la ciudad de Amatunte.

II. Mateo I9. 29, Marcos IO. 3 O.

III. Teodoro I, patriarca de Alejandría que precedió a Juan entre los años 6o7 y 609 (Martindale I992: I275). Fue asesinado en la toma de Alejandría comandada por Nicetas, vid. n. vIII. 
oficios, no estaba permitido conversar de otras cosas, sino que se debía concentrar en los salmos y oraciones y, si por azar alguien intentaba otra cosa, de inmediato era expulsado de la iglesia.

[4] 'Así, sucedió cierta vez que unos ciudadanos de Alejandría, habituados a salir de la iglesia para conversar tras la lectura del Evangelio de la misa, estando él presente, salieron según su costumbre. ${ }^{2} \mathrm{Al}$ descubrir esto, el varón de Dios, saliendo detrás de ellos, que quedaban admirados, se sentó con sus vestimentas sagradas entre los que conversaban. ${ }^{3} \mathrm{Y}$ a los que estaban atónitos a causa de esto dijo: ${ }^{4}$ «No conviene que el pastor se aparte de su rebaño. ${ }^{5} \mathrm{Y}$ por esta razón quiero entrar y salir con ustedes. ${ }^{6}$ Pues podría celebrar la misa en mi propia capilla, pero para tenerlos como compañeros de tan gran beneficio, bajé hasta esta iglesia». 'Tras oír esto, entraron a un tiempo con él y, en adelante, jamás osaron salir antes de que concluyeran los oficios.

[5] 'Así, en ciertas horas y días, quedaba libre para dirimir litigios y disputas a fin de conservar la paz de los suyos; en los restantes, totalmente ocupado día y noche en las alabanzas de Dios, en la predicación y contemplación y en otras necesidades. ${ }^{2}$ Pero al haberse enterado una vez que sus propios porteros no permitían que los pobres ingresaran hasta él, resolvió que dos días en la semana, es decir el miércoles y el viernes, saldría en público al exterior delante de la iglesia y allí acabaría por completo con los motivos de contiendas. ${ }^{3}$ Pero tras ocupar unos cuantos días en esto, condujo a sus ciudadanos a tal grado de concordia que, al salir cierto día según su costumbre y sentarse por cinco horas para dirimir litigios, nadie se presentó ante él para litigar. ${ }^{4}$ Entristecido profundamente por esto, pensando que era o había sido su propia negligencia o defecto, se retiró llorando. ${ }^{5}$ Así, dentro de su casa, a los sirvientes que se lamentaban por su congoja, respondió: ${ }^{6}$ «Pobre Juan, hoy no trabajó para el bien». ${ }^{7 P e r o}$ ellos, por el contrario: ${ }^{8}$ «iPor qué mejor no te alegras, padre, de que condujiste a tu pueblo a tal grado de concordia que ya no persiguen la unidad y la paz humana, sino más bien la angélica?» ${ }^{9}$ Dando gracias a Dios por esto, aceptó el consuelo.

[6] 'Después de esto, el muy piadoso padre, preocupado de que su pueblo no fuera estafado por las astucias de mercaderes y vendedores, ordenó que le fueran llevadas las pesas y las medidas de la ciudad y, una vez que todas estas fueron equiparadas, mandó que en adelante no fueran alteradas por nadie y dispuso un edicto general copiado en tablas sobre las puertas y paredes y en las plazas de la ciudad para que nadie, en el futuro, se arrogara medidas y pesas en la ciudad, puesto que está escrito: ${ }^{2}$ «Una medida y otra medida, una pesa y otra pesa son abominables ante Dios. ${ }^{\text {IV } 3}{ }^{3}$ quienquiera que intentare otra cosa, sus propios bienes le serán arrebatados para ser distribuidos entre los pobres y que no reciba en esto ninguna limosna».

[7] 'Después de esto, supo el varón de Dios que los administradores de las iglesias recibían dádivas de sus propios súbditos y, tras reunirlos, reprendiéndolos suavemente, mostraba cuán detestables son en las Sagradas Escrituras los que reciben dádivas. ${ }^{\vee 2}$ Pero para que, por azar, no se excusaran en razón de su estrechez, les fijó el duplo en las pensiones eclesiásticas, amonestándolos seriamente para que en el futuro no recibieran dádivas en ninguna ocasión. ${ }^{3} \mathrm{Y}$ al asentir ellos y abstenerse de cosas de esta clase, sus ganancias comenzaron a crecer tanto que, regresando al poco tiempo al piadoso pastor y patrono, voluntariamente renunciaron y devolvieron el duplo que habían recibido de él.

IV. Proverbios 2O. IO.

V. Job $15 \cdot 34$. 
[8] 'Pero regresemos ya a su inestimable compasión para relatar por partes sus obras de misericordia. ${ }^{2}$ Ubicado, pues, el venerable obispo en la sede patriarcal, tras llamar a sus sirvientes, dijo: ${ }^{3}$ «Recorran la ciudad y, examinando diligentemente a nuestros amos y hermanos, regístrenlos a todos». «Pero como no entendían, preguntándose entre ellos a quiénes llamaba 'amos', respondió: ${ }^{5}$ «De ellos es el reino de los cielos ${ }^{\mathrm{Vl}} \mathrm{y}$, cuando luego tengamos necesidad, si nos hacemos amigos, nos pueden recibir en los tabernáculos eternos». " 6 Entendiendo, pues, lo que había dicho, recorrieron la ciudad registrando diligentemente a los pobres y necesitados. ${ }^{2} Y$ el número de los registrados fue ocho mil quinientos. ${ }^{8}$ Ordenó que a todos estos les suministraran de sus propios bienes y de los medios de la iglesia. ${ }^{9} \mathrm{Y}$ que a nadie parezca increíble cómo alcanzaba a suministrar tanto y a tantos, puesto que en aquellos tiempos los alejandrinos eran muy ricos, hasta tal punto que no contaban los áureos y argénteos, sino que los pesaban en grandes pesas y medidas. ${ }^{\text {Io }}$ como la fama del santo patriarca era muy célebre, puesto que más allá de una pobre vitualla no retenía nada para sí, sino que todo lo que llegaba a sus manos lo entregaba a los pobres y no se negaba al que le pedía, todos le ofrecían tanto y tantas cosas que, ante él, el tesoro de la iglesia nunca pareció disminuir, sino más bien abundar, como abiertamente declaran sus siguientes hazañas.

[9] 'Así, cierta vez llegó a oídos de un patricio, ${ }^{\text {vil }}$ que supervisaba los negocios reales, la generosidad del patriarca y la inestimable dimensión de sus dones y limosnas, las cuales emanaban de él como una fuente incesante de tesoro y, como canales inagotables, se dispersaban hacia los pobres. ${ }^{2}$ Este vino a él, pidiendo de parte del rey ${ }^{\mathrm{IX}}$ que de tantas riquezas que dispersaba así imprudentemente y sin medida, auxiliara al rey. ${ }^{3} \mathrm{Al}$ oír esto el santo varón, pasó de largo como si fuera sordo; sin embargo, respondió con cautela diciendo: ${ }^{4}$ «Es injusto que los tesoros del rey celestial sean transferidos a las manos del rey terrenal, por lo cual has de saber que no te daré ni una picta de los bienes de los pobres. ${ }^{5} \mathrm{Y}$ aquí tienes el tesoro de Cristo a los pies de mi lecho: podrías arrebatarlo y llevártelo, no recibirlo voluntariamente de nuestra parte». ${ }^{6}$ Entonces el patricio, tras convocar a sus guardias, se llevó todo, dejando una sola moneda de oro, que entre ellos se llama quinario. 7 Pero al bajar por las escaleras del aula patriarcal, encontraron a unos que subían por las escaleras, los cuales venían de África, trayendo cada uno sobre los hombros ánforas llenas de oro, inscriptas por la parte de arriba como sigue. ${ }^{8}$ En la primera, claramente estaba escrito «aquí hay miel de primera»; en la segunda, «aquí hay miel de segunda», y en las otras «aquí hay miel no ahumada». ${ }^{9}$ Cuando el patricio vio y leyó esto, de nuevo ordenó al patriarca que le reservara una porción de

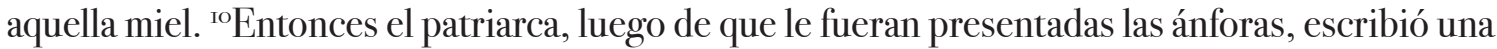
carta para entregar al patricio en estos términos: ${ }^{\mathrm{I}} \ll$ Has de saber, hijo mío, patricio, que no miente quien dijo a los suyos: "Yo no te dejaré ni abandonaré". ${ }^{\text {I2 }}$ Así, muy ciertamente has de saber que

VI. Mateo $5 \cdot 3$.

VII. Lucas I6. 9 .

VIII. Aquí no se indica su nombre, pero sabemos por la versión griega (capítulo Io) que se trata de Nicetas, primo del emperador Heraclio, vinculado a Juan a través de la adelphopoiesis. Este lazo que se efectuaba a través de una ceremonia religiosa, junto con la synteknia y el matrimonio, constituía una herramienta de alianza familiar empleada en las clases sociales más elevadas (Rapp 2004). Nicetas estuvo al frente de la conquista de Egipto y luego fue gobernador de Alejandría. Ante la amenaza que suponía el avance de los persas, en el año 6r9 Juan y Nicetas abandonan Alejandría en dirección a Constantinopla, pero se separan cuando la premonición de su inminente muerte hace decidir a Juan permanecer en su tierra natal. Gregoria, hija de Nicetas, fue esposa de Heraclio Constantino, hijo y sucesor de Heraclio.

IX. Heraclio, emperador entre los años 6ı y 64I, llegó al poder luego de la deposición de Focas. Durante su gobierno debió lidiar con el avance persa sobre el territorio bizantino, que tras entar a Egipto en 6i 7, ocupan Alejandría en el 6i9. Luego de algunas victorias sobre los persas, en 636 sufrió la derrota a manos de los árabes, que avanzaron sobre Siria y Palestina. Heraclio murió hacia el año 64I.

x. Hebreos 13.5 . 
ningún mortal puede agotar los tesoros del rey inmortal, por lo cual te enviamos parte de esta miel». ${ }^{13}$ Entonces el patricio, recibida la carta con el ánfora, al abrir esta, encontró dentro el oro. ${ }^{14} Y$ tras leer la carta del santo varón que decía «has de saber que todas las otras ánforas contienen una miel similar a esta», regresó con prisa al varón de Dios, habiendo llevado consigo sólo una y devueltas todas las que se había llevado, añadidos, además, tres quinarios de su propiedad. ${ }^{5} \mathrm{Y}$ postrándose a sus pies, le pidió ser perdonado, puesto que no había obrado por él mismo, sino por consejo de los malvados, ofreciendo también que cumpliría la pena que le quisiera imponer por esto. ${ }^{16}$ Tras oír esto, el patriarca se admiró de su humildad y reconfortándolo con dulces palabras, lo despidió y, tras recibir lo que le había llevado, lo recibió en adelante con amistad y gran familiaridad.

[Io] 'Así, sucedió un día domingo que, al descender el varón de Dios a la iglesia, encontró a uno de sus conciudadanos, rico y católico, pero robado por ladrones esa misma noche. ${ }^{2} Y$ tras narrarle la desdicha que le había ocurrido, el santo varón llamó a su tesorero, ordenándole que le cediera quince libras de oro, llamadas comúnmente 'rotas'. ${ }^{3}$ Pero el camarlengo, tras armar un plan con el ecónomo de la iglesia, le dio sólo cinco rotas al que había sido robado. ${ }^{4} \mathrm{Al}$ volver, pues, el varón de Dios de la iglesia, se le presentó una viuda, que tenía un solo hijo, ofreciéndole un cofre, que contenía cinco talentos de oro, llamados comúnmente quinarios, y diciendo: ${ }^{5}$ Ofrezco a la iglesia este don». ${ }^{6} \mathrm{Y}$ aceptado el don, al llegar el patriarca a su recámara, llamó a su tesorero, inquiriéndole cuánto le había entregado al hombre anterior. ₹Este respondió: ${ }^{8}$ «Cuanto ordenó su santidad». ${ }^{9} \mathrm{Y}$ al descubrir en su espíritu el varón de Dios que el tesorero había mentido, hizo llamar al que había sido robado, tomándole juramento para que dijera verdaderamente cuánto había recibido

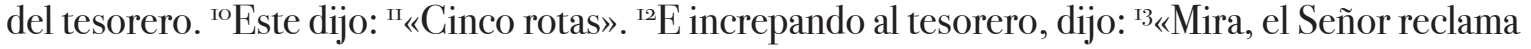
de nosotros los diez quinarios, que con los otros cinco nos habría entregado la viuda, si al que fue robado le hubiesen dado cuanto les ordenó mi cuidado paterno». ${ }^{14} Y$ queriendo probar esto, la convocó, mandándole que les certificara cuánto había dispuesto dar a la iglesia. ${ }^{15} \mathrm{Y}$ al venir esta y traer el resto, narró que ella misma había escrito en un papel que daría quince quinarios, pero luego de orar por una hora, abrió de nuevo el papel y, restados diez, encontró en ella sólo cinco. ${ }^{16} \mathrm{Y}$ dijo: ${ }^{17} \ll$ ¡Por mí misma!, tal vez no place a Dios que esta vez done más. ${ }^{18} Y$ por ello, tras conservar diez, sólo traje cinco». ${ }^{19}$ Pero al retirarse la viuda, cayeron a sus pies los transgresores de la orden, pidiendo que esta vez los perdonara misericordiosamente, prometiendo con firmeza que en adelante no pasarían por alto ninguna de sus órdenes.

[II] 'En aquel tiempo sucedió que las regiones limítrofes eran devastadas por los bárbaros y los infieles y muchos de los cristianos huían a Egipto y, a causa de la fama de generosidad del santo varón, venían hacia Alejandría hasta él como a un puerto de salvación y lugar de refrigerio. ${ }^{\mathrm{x} 2}$ Así, él mismo los recibía y asistía de palabra y obra, no como a extranjeros o huéspedes, sino como a familiares y hermanos, poniendo por separado a los enfermos y débiles en un gran hospital que había hecho construir para refugio de esos. ${ }^{3}$ Así, disponía que allí les suministraran lo necesario hasta que se recuperaran y se marcharan voluntariamente. ${ }^{2}$ Pero a los sanos que acudían a él, hacía que a cada hombre le dieran una pieza de oro que pesaba diez denarios, llamada comúnmente quilate; además, a cada mujer dos de estas piezas. ${ }^{5} \mathrm{Y}$ cuando alguien pedía, a condición de la vestimenta y del rostro de estrechez, no era apartado de este don. ${ }^{6} \mathrm{Y}$ puesto que sus ministros murmuraban sobre algunos que venían a él vestidos elegantemente, los reprendió ásperamente,

XI. Luego de que fuera recuperado de la ocupación persa sasánida en el 629, Egipto queda bajo el dominio bizantino enfrentando las consecuencias del avance árabe, que se apoderaría definitivamente de él entre el 639 y 64I. Durante su Patriarcado Juan había dado refugio a quienes huían de persas y árabes. 
diciendo: " «El Señor omnipotente que dijo "da a todo el que te pide" Juan tenga tesoreros que discutan sobre quién entre los que piden está necesitado y quién no está necesitado, sino que estas cosas, que son de Cristo, entregadas a nuestra administración para todos los que piden, sean repartidas por Cristo abundante y alegremente, lejos de la murmuración o discusión o acusación. ${ }^{8}$ Puesto que si todos los que son de Alejandría vinieran a pedir algo, no podrían agotar los tesoros de Cristo y sería más tolerable que yo fuera mezquino con mis propios hijos y padres que con los miembros de Cristo y pobres».

[I2] 'En esos tiempos, se acercó al varón de Dios uno de Nubia, ${ }^{\text {XII }}$ antes gran comerciante en una nave de mar, pero abatido por la fortuna y, tras pedir auxilio, el santo varón le dio cinco rotas de oro. ${ }^{2}$ Este, luego de adquirir con ello las mercancías necesarias, comenzó a navegar con la nave cargada. ${ }^{3} \mathrm{Y}$ agitado el mar impetuosamente, tras haber sido todos arrojados, volvió a Alejandría con la nave vacía. ${ }^{4}$ Y al regresar al santo patriarca con lágrimas y angustia de corazón, de nuevo apeló a su misericordia. ${ }^{5 \mathrm{El}}$ santo patriarca le respondió: ${ }^{6}$ «Si no hubieses mezclado tu perniciosa y fraudulenta riqueza con la riqueza de la iglesia, no habrías naufragado». " $\mathrm{Y}$ de inmediato dispuso que le dieran otras diez rotas de oro, haciéndole jurar que no mezclaría con estas nada de su propia riqueza. ${ }^{8}$ Este, luego de comprar mercancías con ese mismo oro, comenzó a navegar otra vez con la nave cargada y, al alejarse por un día del puerto, atrapado por una gran tempestad, perdió totalmente la nave destruida junto con las mencionadas mercancías, habiendo sido salvados él mismo con sus compañeros por voluntad y virtud de Dios. ${ }^{9} \mathrm{Y}$ al volver a Alejandría, no osaba regresar al varón de Dios, sino que como desesperado quería degollarse a sí mismo. ${ }^{\circ}$ Luego de descubrir esto en su espíritu, el varón de Dios dispuso que aquél fuera sin vacilación alguna. "'Al ir, pues, con tristeza y dolor, con los cabellos esparcidos, habiendo rociado su cabeza y rostro con polvo y ceniza, se arrojó delante de él. ${ }^{\mathrm{I} 2} \mathrm{El}$ santo varón, hablándole suavemente, lo consolaba, diciendo: ${ }^{13}$ «No temas, puesto que en adelante no naufragarás y no habrías naufragado esta vez, si no hubieses comprado tu nave con tu riqueza injusta y mal adquirida». ${ }^{14} \mathrm{Y}$ de inmediato dispuso que le dieran una de las naves de la iglesia cargada de trigo. ${ }^{5} \mathrm{Y}$ le fue entregada con veinte mil modios de trigo. ${ }^{16} \mathrm{Y}$ al alejarse pues, con esta del puerto, navegando prósperamente por veinte días y noches, ignoraba a dónde se dirigía, a no ser porque cada noche veía al varón de Dios que sostenía el timón y decía: ${ }^{17} \ll$ No temas, puesto que navegas bien y rectamente». ${ }^{18} Y$ así, navegando con admirable velocidad, llegaron a Britania, donde había una gran hambruna. ${ }^{19} Y$ los habitantes, acercándose a él, le ofrecían un áureo por cada modio o, por una carga de nuestra vasija en trigo, la misma carga en estaño. ${ }^{20}$ Este pidió que le dieran la mitad del precio del trigo en oro y la mitad en estaño. ${ }^{21} Y$ tras recibir esto, queriendo volver a Alejandría, en medio del camino se desvió al puerto de una ciudad y, descendiendo allí, puso a la venta una parte del estaño. ${ }^{22} Y$ luego de fijar el precio, el comprador quiso probar el estaño y, tras arrojarlo al fuego, se vio claramente que era plata pura. ${ }^{23} \mathrm{Y}$ acercándose al vendedor, lo increpa, diciendo: ${ }^{2}{ }^{4}$ ¿Por qué, tentándome maliciosamente, me pusiste una trampa para que yo, recibiendo plata por estaño, te engañara?» ${ }^{25} \mathrm{El}$ vendedor, negando con un improperio, lo condujo a la nave para que viera el resto del estaño. ${ }^{26}$ Tras verlo y probarlo, se vio que todo era plata. ${ }^{27}$ Juró, entonces, el vendedor que él no sabía, sino que esto había sucedido por los méritos del santo patriarca y por la virtud de aquél que convirtió el agua en vino. ${ }^{28}$ Dieron gracias al Altísimo por esto y así, navegando prósperamente un poco más lejos, llegaron a Alejandría. ${ }^{29} \mathrm{Y}$ luego de narrar todo lo que había

XII. Lucas 6. 30 .

XIII. En las distintas versiones griegas sólo se dice que el navegante era extranjero, por lo que el origen nubio del navegante parece ser una innovación de esta traducción latina. 
pasado al santo patriarca, le presentó la plata señalada. ${ }^{30}$ Este, rechazándola por completo, cedió todas las cosas junto con el recipiente mismo al comerciante.

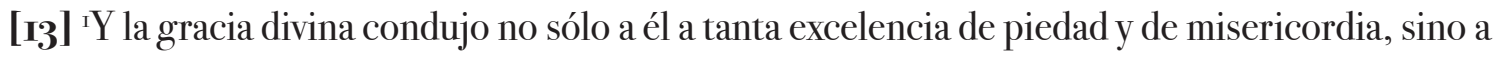
muchos otros a través de él mismo. ${ }^{2}$ Había, en efecto, en otra ciudad vecina, un obispo mezquino y poco misericordioso llamado Troilo. ${ }^{\text {XIV }}{ }^{3}$ Este, luego de reunir treinta rotas de oro, vino a Alejandría para comprar vasos de oro y de plata. ${ }^{4} \mathrm{Y}$ habiendo venido a visitar al santo patriarca según su costumbre, el santo varón, tras tomar consigo a dicho obispo, descendió a su hospital para visitar a sus enfermos. ${ }^{5}$ Había, pues, un espacioso hospital dentro de la inmensa curia, cerrado por una puerta y un guardia y dividido en muchos habitáculos distintos, para que allí mismo las salas fueran ocupadas según las distintas clases de enfermedades. ${ }^{6}$ Entonces, tras visitarlos, exhortó al obispo para que se compadeciera de ellos. ${ }^{7}$ Este, movido por algo de piedad y de vergüenza, les donó las mencionadas rotas y, luego de recibir la venia del santo patriarca, al volver a su hospedaje, comenzó a arrepentirse de lo que había hecho y, profundamente entristecido, cayó con fiebre. ${ }^{8} \mathrm{Y}$ tras ser llamado al día siguiente a la mesa del santo varón, se excusó por su debilidad. ${ }^{9} \mathrm{Y}$ de inmediato el santo varón, descubierta en su espíritu la causa de la enfermedad, dijo: ${ }^{\mathrm{10}}$ «No corresponde que nuestro compañero sufra en nuestra presencia». "Y levantándose, tras tomar consigo la misma cantidad de rotas de oro, descendió a visitar al enfermo. ${ }^{12} Y$ sonriendo, le dijo: ${ }^{13}$ «No creas que pedí tu donación con ánimo de quitártela, sino que lo dije bromeando». ${ }^{\text {I }}$ Y luego de poner el oro delante de él, dijo: ${ }^{5}$ «Aquí tienes lo que es tuyo. ${ }^{16}$ No es conveniente que sufras y te enfermes a causa de esto». ${ }^{17}$ Entonces el obispo, vuelto a la alegría y al gozo y al alivio, confesó que era verdad que sufría a causa de esto. ${ }^{18} \mathrm{El}$ santo le respondió: ${ }^{19}$ «De este modo, te reembolsé dando la misma cantidad a los pobres, para que, cediéndome toda la recompensa, redactes así una carta de tu propia mano». ${ }^{20}$ Este, tras tomar el cálamo, escribió: ${ }^{21}$ «Señor Dios omnipotente, concedo al señor patriarca toda la ganancia de esta limosna». ${ }^{22} \mathrm{Y}$ levantándose, partió con el señor patriarca. ${ }^{23} \mathrm{Y}$ luego de comer con gozo, la noche siguiente vio en sueños un palacio inapreciable de oro purísimo sobre cuya puerta colgaba una inscripción en una tabla con estas palabras: ${ }^{24}$ «Aquí hay un palacio de gozo incesante, que fue preparado por el obispo Trófilo a causa de sus limosnas». ${ }^{25} \mathrm{Y}$ mientras repetía esto para sí gozando, de repente apareció un varón potente con un noble séquito y, acercándose a la mencionada puerta, exclamó: ${ }^{26}$ «Quiten ya esta tabla y pongan esta en su lugar». ${ }^{27}$ Pero en esta segunda estaba la siguiente inscripción: $\aleph^{28} A q u i ́$ hay un palacio de gozo incesante, que el patriarca Juan adquirió para sí del obispo Trófilo». ${ }^{29}$ Perturbado, pues, por esta visión, pasó la noche en vela y, regresando al varón de Dios con dolor de corazón, le expuso su visión. ${ }^{30} Y$ luego de pedir perdón, fue consolado por el santo patriarca, que le hizo ver cuánto beneficio trae la piedad y la limosna. ${ }^{31} \mathrm{Y}$ así, al regresar el obispo a su lugar, fue en adelante misericorde y generoso.

[I4] 'En aquel tiempo, el santo varón supo que un devoto a Dios de nombre Modesto ${ }^{\mathrm{xv}}$ reparaba en Jerusalén los lugares santos asolados por los infieles y, queriendo ser parte de tan grande beneficio, envió hacia allí mil bizancios y mil sacos de trigo y mil sacos de legumbres y mil vasijas llenas de pescados salados y mil ollas llenas de jarabe y mil rotas de hierro y mil operarios, rogando así: ${ }^{2}$ «Perdóname, porque envié poco. ${ }^{3}$ Antes bien querría ir hasta allí, si pudiese hacerlo, y trabajar con mis propias manos. ${ }^{4} \mathrm{Y}$ no escribas, por esto, mi nombre entre los contribuyentes, mas ruega al piadosísimo padre para que sea escrito en el libro de la vida».

XIV. El manuscrito presenta una lectura deturpada del nombre Troilo (Trophila).

XV. Aunque se trata de un nombre latino, es éste otro nombre propio en el que el manuscrito ofrece una lectura errónea. Vid. n. XIV, XIX, XX y XXI. 
[55] 'En tiempos del santo patriarca había un rico de Alejandría, llamado Pedro, que no tenía misericordia hacia los pobres. ${ }^{2}$ Un día, por cierto, reunidas todas juntas las multitudes de pobres y sentadas al sol, comenzaron a concertar entre sí, bendiciendo a los ciudadanos misericordiosos y, por el contrario, maldiciendo a los otros. ${ }^{3}$ Finalmente, se volvieron al mencionado Pedro, indagando uno a uno si alguno de ellos había recibido un beneficio de este y no encontraron ni uno solo. 4 Uno de ellos se levantó, diciendo: ${ }^{5}$ ¿QQué me darán si obtengo de él una limosna?» ${ }^{6} \mathrm{Y}$ prometieron que le darían. ${ }^{2}$ Este, postrándose en la puerta del rico, esperando que viniera, vio finalmente que venía con los asnos cargados de pan y le pidió una limosna. ${ }^{8}$ Este, enfurecido por el llamado del pobre, se volvía aquí y allí, buscando una piedra para arrojarle y no la encontraba, pero tras agarrar un pan, le pegó con este al pobre en la cara con un gran golpe. ${ }^{9} \mathrm{El}$ pobre, por cierto, recogiendo el pan, va hacia sus compañeros, diciendo y jurando: ${ }^{\text {Io }}$ «Aquí está el pan que acabo de recibir de Pedro». "Pero al cabo de dos días, al enfermarse Pedro, vio en un sueño que él se hallaba en un juicio, suplicando por todos sus hechos, que eran sopesados. ${ }^{12}$ De una parte, se hallaban seis horribles y negros, acumulando sus obras malas en el platillo y, de la otra parte, los blancos y bellos, buscando qué contraponer y no lo encontraban, sino que sufrían. ${ }^{13}$ Finalmente, uno de ellos dijo: ${ }^{1}{ }^{4}$ Aquí hay un pan, que una vez arrojó perturbado a un pobre». ${ }^{15} \mathrm{Y}$ colocado el pan en el platillo, pesó igual que todas las cosas malas. ${ }^{16} \mathrm{Y}$ los blancos, alegres, le dijeron: ${ }^{17}$ \&edro, ve y trata de reunir más. ${ }^{18}$ De otro modo, caerás en la parte de los horribles». ${ }^{19}$ Pero al despertarse y advertir la visión, dijo para sí: ${ }^{20}$ «Si este pan dado con mal ánimo me arrebató hasta ahora del poder de los malvados, cuánto más las limosnas reunidas con misericordia y alegría». ${ }^{21} Y$ desde aquel día comenzó a compadecerse plenamente de los pobres en el afecto y en la acción. ${ }^{22}$ Cierto día, cuando regresaba de la iglesia, encontró a un etíope, que recientemente había escapado desnudo de un naufragio y, luego de quitarse la elegante vestimenta que llevaba puesta, se la dio, rogando y suplicando que se la pusiera por Dios. ${ }^{23}$ Pero el pobre, avergonzado de usarla, se alejó. ${ }^{24} Y$ mientras la vendía en la plaza, Pedro se dolió al ver esto y, encerrándose en su recámara, se lamentó, diciendo: ${ }^{25}$ «o era yo digno de recibir del pobre la recompensa de este beneficio». ${ }^{26} \mathrm{Y}$ atormentándose, vio ante sí a un hombre bellísimo, más reluciente que el sol, que sostenía una cruz sobre la cabeza, cubierto con la mencionada vestimenta y que decía: ${ }^{27}$ «Pedro, ¿por qué lloras?» ${ }^{28}$ Este respondió: « «Porque tu pobre me despreció mucho». ${ }^{30} \mathrm{Y}$ el Señor a él: ${ }^{3 \mathrm{~T}}$ ¿ ¿Reconoces esta vestimenta? ${ }^{32}$ Desde aquella hora en que se la diste al pobre, yo mismo me cubrí con ella». ${ }^{33} \mathrm{Y}$ al despertarse, dio gracias a Dios, diciendo: ${ }^{34}$ «Felices los pobres, ¡vive el Señor! por el cual entendí que ellos mismos portan la persona de Cristo; no quiero morir hasta ser uno de ellos». ${ }^{35} \mathrm{Y}$ de inmediato, llamando a sí a uno de sus sirvientes, dice: ${ }^{36}$ «Te confío mi gran secreto, el cual, si lo revelas a alguien, te venderé a los bárbaros. ${ }^{37}$ Toma estas diez rotas de oro y con ellas cómprame mercancías, que junto conmigo transportarás a Jerusalén para la venta. ${ }^{38} Y$ cuando las hayas vendido, no te retrasarás en venderme también a mí mismo allí a alguien y todo el pago lo darás a los pobres». ${ }^{39}$ Mas el sirviente, atónito, se rehusaba a hacer esto, pero vencido por las amenazas y la insistencia de su señor, asintió y cumplió las órdenes de su señor. ${ }^{40}$ Vendió, pues, a su señor a un amigo suyo por el precio de treinta bizancios, entregándoselo y diciendo: ${ }^{41}$ «Este esclavo es un varón bueno y bendito y tus bienes serán multiplicados por Dios a través de él». ${ }^{42} Y$ diciendo esto, mientras despedía a su señor, partió prometiendo que daría el pago a los pobres por Cristo y que no lo revelaría a nadie. ${ }^{43}$ Sirvió, entonces, Pedro humildemente a su señor en todo, pobremente vestido, insistiendo en los ayunos, las vigilias y las oraciones, considerado como un simple por los otros sirvientes y sobrellevaba pacientemente los insultos y golpes provocados por ellos. ${ }^{44}$ Y cuando se dormía, veía a Cristo en la forma antedicha, vestido con la mencionada ropa y sosteniendo en su mano el pago de su venta y diciendo: ${ }^{45}$ «Hermano Pedro, no te entristezcas. ${ }^{46}$ Aquí está tu pago, que yo recibí, condúcete 
pacientemente y soporta, hasta que llegue el tiempo de que sea revelada tu justicia». ${ }^{47}$ Pero su señor admiraba su humildad, la paciencia y los esfuerzos. ${ }^{8} \mathrm{Y}$ puesto que el Señor omnipotente había bendecido su casa a causa de él, muchas veces lo habría emancipado, si él lo hubiese consentido. ${ }^{49}$ Pero pasado el tiempo, llegaron de Alejandría a Jerusalén unos cambistas. ${ }^{50} \mathrm{El}$ señor de Pedro los invitó a un convite. ${ }^{5}$ Pero al sentarse estos a la mesa, vieron a Pedro que les servía y murmuraban entre sí, diciendo: ${ }^{52}$ «¿Acaso este no es Pedro, el prepósito de Alejandría?» 53Pero Pedro, que tenía esto en cuenta, se ocultaba de sus miradas. ${ }^{54}$ Pero ellos le decían a su señor: ${ }^{55}$ «ste esclavo tuyo es grande y uno de los más grandes de nuestra tierra». ${ }^{5}$ Pero uno de ellos, observando atentamente a Pedro por tercera vez, dijo: ${ }^{57}$ «En verdad este es Pedro. ${ }^{5} \mathrm{Me}$ levantaré y lo detendré, puesto que nuestro rey sufre mucho y está preocupado por él». ${ }^{59} \mathrm{Al}$ oír esto Pedro, tras dejar la escudilla que llevaba, se fue hacia la puerta. ${ }^{6} \mathrm{El}$ portero era sordo y mudo de nacimiento. La familia le hablaba con gestos y signos. ${ }^{6}$ Pero Pedro, apresurándose, le dijo: ${ }^{62}{ }$ En nombre de Jesucristo, ábreme, hermano». ${ }^{6}$ Ante esta voz, se abrieron sus oídos y se soltó su lengua. ${ }^{6} Y$ Y respondiéndole, dijo: ${ }^{65}$ «Con gusto, padre». ${ }^{66} \mathrm{Y}$ abriendo la puerta de inmediato, lo dejó ir y se alejó. ${ }^{6}$ Pero el portero sordo, subiendo y llamando a su señor, dijo: ${ }^{68}$ «Señor, señor, aquél que servía en la cocina, partió. ${ }^{69}$ Miren que no huya de ustedes, puesto que es un hombre santo y siervo de Dios, puesto que, mientras me rogaba que le abriera, vi que de su boca las palabras salían como una llama de fuego, las cuales, al tocar mis oídos y lengua, de inmediato todo se abrió». ${ }^{7}$ Entonces todos se levantaron para seguirlo y, al no hallarlo, volvieron, dando gracias a Dios y haciendo penitencia porque habían pecado contra él y los que oyeron esto, glorificaron a Dios. ${ }^{7}$ Amén.

[I6] 'Así, cierto día, mientras el santo patriarca leía las vidas de los padres, encontró el admirable ejemplo de misericordia y generosidad de San Serapión. ${ }^{\text {XV }}{ }^{2}$ Pues cuando un pobre le pidió limosna y no encontró algo a mano para darle, le ofreció al pobre, tras quitársela, la túnica que llevaba puesta. ${ }^{3} \mathrm{Y}$ poco después, encontró a otro que igualmente le pedía una ayuda. ${ }^{4}$ Este, tras quitarse de nuevo la única camisa que le quedaba, la entregó al pobre y quedó desnudo por Cristo con toda su vergüenza al descubierto, sólo con el libro del Evangelio en sus manos. ${ }^{5}$ Pero al llegar a los suyos y, tras ser interrogado por ellos sobre quién lo había desvestido, luego de abrir el libro del Evangelio que sostenía, respondió: ${ }^{6}$ «El que dijo esto y quiso que fuera escrito: "Da a todo el que te pide"». ${ }^{\text {xvI }}$ ${ }^{7}$ Y nuevamente a otros que le pedían, como no tenía nada, salvo únicamente el Evangelio, lo vendió y dio a los pobres. ${ }^{8} \mathrm{Y}$ al preguntar su clérigo qué había hecho con el libro del Evangelio, respondió:

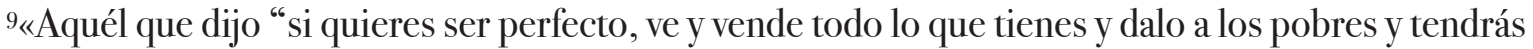

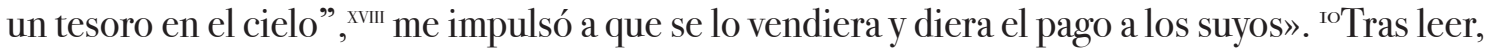

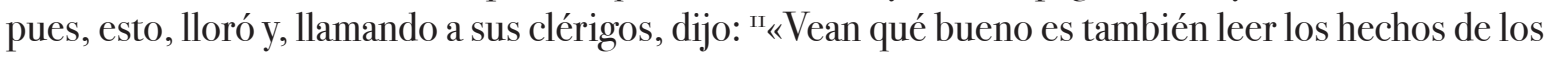
santos. ${ }^{12}$ Por cierto, yo creía que obraba por Cristo, distribuyendo entre los pobres aquellas cosas que eran dispensadas a mí y a la iglesia por los fieles piadosos, pero no había prestado oídos a la generosidad de aquellos que se desnudaban totalmente y vendían sus propios cuerpos para dar a los pobres». ${ }^{33}$ Después de esto, el hombre de Dios se entusiasmó mucho más con las obras de piedad.

[17] 'Así, una vez llegó a Alejandría un joven monje para peregrinar y orar en la memoria del beato Cirilo. ${ }^{\mathrm{XIx}}{ }^{2} \mathrm{Y}$, mientras recorría la ciudad con una bella jovencita, pedía limosna y muchos se

XVI. Serapión, conocido con el apodo de "el sindonita” por la única vestidura que llevaba, un sudario ( $\left.\sigma \iota v \delta \omega^{\prime} v\right)$, fue un monje egipcio del siglo IV. Las anécdotas de su vida son narradas en la Historia Lausiaca de Paladio (vid. BHG I435I $438 \mathrm{v})$.

XVII. Lucas 6. 30

XVIII. Lucas I8. 22

XIX. Se trata de otra lectura errónea de un nombre propio, ya que se refiere a san Ciro, venerado junto con 
escandalizaban de ellos. ${ }^{3}$ Acusado, finalmente, ante el santo patriarca, dispuso que los capturaran y los trasladaran por separado a la cárcel. ${ }^{4}$ Pero sus ministros, propasándose, maltrataron al monje y lo azotaron fuertemente. ${ }^{5}$ Así, durante la noche, el monje se le apareció en sueños al santo patriarca y le mostró su espalda, diciendo: ${ }^{6}$ « ¿Acaso te agradan, padre, estos flagelos? ${ }^{7}$ Mira que en este hecho es grave tu negligencia y culpa». ${ }^{8} \mathrm{Y}$ con estas palabras, desapareció. ${ }^{9}$ Por la mañana, en verdad, hizo que lo llevaran ante él y apenas podía sostenerse sobre sus pies. ${ }^{\circ}$ Así, ordenó que le mostrara su espalda y cuerpo para probar lo que había visto. "IY ordenó que envolvieran sus partes pudendas con un paño para inspeccionarlo completamente. ${ }^{12}$ Pero por voluntad del Señor, cayó de repente el paño y se vio claramente que era eunuco y castrado, pero exteriormente no se notaba a causa de su juventud. ${ }^{13} Y$ al ver las heridas de su espalda, llamó a los que habían hecho esto y, tras removerlos de sus cargos, los suspendió por tres años de la sagrada comunión. ${ }^{{ }^{1}}$ Así, excusándose porque esto había sucedido sin que él lo supiera, reprendió al monje, diciendo: ${ }^{15}$ «Es muy deshonesto deambular con una jovencita con hábito monacal, para que el nombre del Señor y la condición religiosa no sean blasfemados por tu causa entre la gente». ${ }^{16} \mathrm{Pero}$ el monje con toda humildad comenzó a narrarle por qué y de qué manera hacía esto, diciendo: ${ }^{17}$ «Al venir a Alejandría para peregrinar y orar, encontré a esta en Gaza, la cual confesaba que era judía y que quería ser bautizada. ${ }^{80} Y o$, en verdad, temiendo ofender a Dios, si despreciaba tan piadosa obra, tras tomarla conmigo en el camino y traerla hasta aquí, la hice bautizar. ${ }^{19} \mathrm{Y}$, formándola en la profesión de fe, pensé recolectar limosna para su causa y colocarla en alguna parte en una comunidad de religiosas. ${ }^{20} \mathrm{Y}$ no pensaba que los hombres podían sospechar de un castrado así». ${ }^{2 T}$ Tras oír esto, el santo patriarca, volviéndose a sus compañeros, daba gracias a Dios, porque tuvo así escondidos a sus propios santos. ${ }^{22} \mathrm{Y}$ tras narrar su visión anterior, dispuso que dieran al monje cien bizancios. ${ }^{23} \mathrm{El}$ monje, rechazándolos, dijo: ${ }^{24}$ «Aquellos que confían en el Señor no necesitan tales cosas». ${ }^{25} Y$ por estas palabras, conocieron todavía más su santidad y, despidiéndolo con una genuflexión, el patriarca se retiró. ${ }^{26}$ Así, desde entonces, el beato patriarca amó todavía más a los monjes y los honró. ${ }^{27} \mathrm{Y}$ para la obra y refugio de estos, mandó a hacer habitaciones separadas en su propio hospedaje y que allí mismo les suministraran apropiadamente las cosas necesarias.

[18] 'En aquellos tiempos, había en cierto monasterio fuera de Alejandría un monje sexagenario, religioso de espíritu y obras, llamado Vitalio. ${ }^{\mathrm{xx}}{ }^{2}$ Este, habiendo oído sobre la fama de misericordia y de obras piadosas del santo patriarca, pensó hacer, a semejanza de él, algo magnífico a los ojos de Dios, pero muy vergonzoso a los ojos de los hombres, queriendo también probar con esto al mismo tiempo, si el santo varón se alteraba fácilmente ante las murmuraciones o si más bien tenía dentro de sí discernimiento de espíritus. ${ }^{3} Y$ tras abandonar el monasterio, comenzó a residir en la ciudad y a vivir del trabajo de sus manos. «Pero cada día, luego de haber recibido de su jefe el jornal, compraba y comía por una sola moneda o picta un alimento de la clase más vulgar de legumbres, que se llama comúnmente lupín y se ingiere con agua sola, y de esto vivía. ${ }^{5}$ Pero con el resto de su jornal se compraba por toda la noche el cuerpo de una prostituta, haciendo con ella un trato para que no

su compañero Juan en un santuario localizado en Menutis, que constituía por entonces un importante centro de peregrinación. A estos santos del siglo IV, Sofronio, biógrafo también de Juan el Limosnero, les dedicó una obra en la que se recogen sus milagros (vid. BHG 0477-0479a). Leoncio menciona a los santos Ciro y Juan en el prólogo y en el capítulo 3 О [3I], pero en el 23, que se corresponde con este capítulo en la versión larga, no se incluye el nombre de Juan y presenta la variante Kú La versión metrafrástica agrega aquí el nombre de Juan (vid. BHG o888, PG I4. 936) y lo mismo hacen la traducción latina amalfitana (Chiesa r995: 88) y la siríaca (Venturini 2020 II: 46). El topónimo actual Aboukir precisamente hace referencia al culto del santo.

xx. Se trata de otro caso en el que un nombre de origen latino que aparece deturpado (Petalius). 
pudiera pecar con alguien durante esa noche. ${ }^{6}$ Pero, además, él mismo permanecía toda la noche junto a ella para ver que nadie entrara a pecar. ${ }^{2}$ Y estando en vela por la mayor parte de la noche en algún rincón del prostíbulo y cantando salmos con numerosas genuflexiones, oraba para que el Señor omnipotente mirara misericordiosamente a la que lo hospedaba y la liberara del pecado. ${ }^{8}$ Pero al aclarar el día, la encomendaba a Dios, advirtiéndole que se abstuviera de pecar y haciéndole jurar que no revelaría a nadie los hechos y dichos del monje. ${ }^{9} \mathrm{Y}$ así trabajando el día siguiente, apartaba igualmente con otra prostituta por la noche. ${ }^{\text {ro }} \mathrm{Y}$ así, cada día, asechaba a cada una haciendo lo mismo. "Pero como muchos ciudadanos lo criticaban por esto en la ciudad y discutían con las mencionadas prostitutas sobre él, sucedió una vez que una de ellas reveló a algunos sus hechos

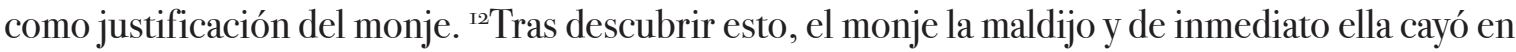
una alienación mental. '3Pero muchos decían que esto no le había ocurrido a causa de la maldición del santo, sino porque había mentido para encubriles el delito. ${ }^{14}$ Así, ninguna de ellas osaba confesar la verdad para no sufrir del mismo modo. ${ }^{5}$ Pero él mismo, terminado su trabajo por la tarde, en presencia de muchos que lo oían, hablándose a sí mismo, decía: ${ }^{16}$ «Hermano Vitalio, ve esta noche a deleitarte con esa que te espera». ${ }^{17}$ Por ello los que oían lo insultaban severamente. ${ }^{18} \mathrm{El}$ mismo les respondía: ${ }^{19}$ ¿¿No creen que también los monjes tienen un cuerpo carnal como ustedes? ${ }^{20} \mathrm{Han}$ de saber, por cierto, que yo también soy hombre como ustedes y tengo también voluntad humana como los demás». ${ }^{2}$ Pero aquellos, por el contrario: ${ }^{22}$ «Arroja el hábito monacal y cásate, a fin de que no sea vituperado por causa tuya el nombre de los monjes». ${ }^{23}$ Pero él mismo decía: ${ }^{24}$ «Déjenme en paz. ${ }^{25}$ ¿Acaso son mis jueces? ${ }^{26}$ Piensen sobre ustedes. ${ }^{27}$ Yo no los juzgo. ${ }^{28} \mathrm{El}$ único, que juzgará a ustedes y a mí del mismo modo, está en el cielo». ${ }^{29}$ Finalmente, los clérigos aconsejaron sobre este al señor patriarca, pero no los oía, sino que les decía: ${ }^{3}$ «Absténganse de infamar a los monjes. ${ }^{3}$ Recuerden lo que hizo el ilustre emperador Constantino, que en el sínodo de Nicea ${ }^{\mathrm{XX1}}$ recogiendo en un montón todas las cartas escritas para infamación y vituperio de los monjes y presentadas ante él en público , las arrojó al fuego frente a todos, diciendo: ${ }^{32 "}$ "Si yo viera con mis propios ojos que ellos pecan, les pondría mi manto, cubriéndolos, para que no sean vistos por los hombres. 33 Pero ustedes hacen lo contrario". ${ }^{34}$ Recuerden lo que cometieron aquella vez contra el otro joven monje que andaba con la jovencita, contra el cual me hicieron pecar». ${ }^{35}$ Así, el monje permanecía en dicha situación, rogando a Dios que perdonara a los que pensaban mal sobre él y lo criticaban. ${ }^{36} \mathrm{Y}$ muchas de dichas mujeres, por su advertencia y ejemplo, abandonando los prostíbulos, hicieron penitencia, algunas casándose, algunas ingresando en una comunidad de religiosas. ${ }^{37 P e r o}$ un día, cuando el monje salía del hospedaje de la principal de las prostitutas, encontró a uno de los rufianes y, alzando la mano, le dio una bofetada al monje, diciendo: ${ }^{38}$ «Viejo ruin, ¿hasta cuándo llevarás esta vida tan deshonesta?». ${ }^{39} \mathrm{El}$ monje a él: ${ }^{\circ}$ «Por cierto, has de saber, miserable, que en breve habrás sido golpeado de tal manera que los ciudadanos alejandrinos se reunirán sorprendidos para mirar». ${ }^{4}$ Assí, el monje tenía una celda junto a la puerta oriental de la ciudad cerca de la iglesia, en la cual se reunían con él las mujeres y allí, luego de muchas advertencias y trabajos, se durmió en el Señor. ${ }^{42} \mathrm{~A}$ esa misma hora fue hasta el antedicho rufián uno muy desagradable y, pegándole con un gran golpe, lo hizo caer a tierra. ${ }^{43}$ Este, después de levantarse, corrió a la celda, proclamando su propia culpa y pidiendo misericordia con las vestiduras rasgadas. ${ }^{4}$ Mientras se acercaba a la puerta, encontró un

XXI. El manuscrito presenta adjetivo topónimo bajo la forma evidentemente errónea de Vicena, ya que se refiere al Primer Concilio de Nicea, del año 325. En la versión griega larga (capítulo 37 [38]) sólo se lo menciona como rìv

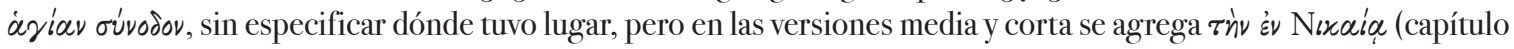
XXXVI). En la traducción latina de Anastasio (capítulo XXXV) de la edición de la Patrologia Latina de Migne se lee secunda synodus in Nicaea, un claro error de tipo paleográfico (PL 73. 37O, vid. Bohdziewicz 2019: 47 I, n 34). Acaso de esta lectura del manuscrito arlatense, más que un procedimiento propio de la traducción medieval, pueda suponerse la presencia de esta variante en el modelo subyacente. 
demonio, que lo arrojó a tierra y lo ahogaba. ${ }^{45}$ Así, el pueblo, yendo tras él, rodeaba al que sufría. ${ }^{4} 6$ Uno de ellos, entrando a la celda, halló su cuerpo sobre las rodillas y vio que en el suelo de la celda estaba escrito: ${ }^{4}{ }^{4}$ Hombres de Alejandría, no juzguen a nadie antes de tiempo, hasta que venga el que iluminará lo que está cubierto de tinieblas». ${ }^{x x i} 4^{8}$ Pero al salir el mismo de la celda y llamar a otros para que vean esto, el demonio dejó al que flagelaba. ${ }^{49}$ Este, llorando y haciendo penitencia frente a todos, narró cómo lo había golpeado el santo de Dios y lo que había oído de él. ${ }^{50}$ Luego de esto, corriendo hasta el beato patriarca, le contó cada cosa en orden. ${ }^{5}$ Este, levantándose, tras ordenar una procesión de clérigos, fue hacia su celda y dio gracias a Dios por lo que leyó en las letras del suelo, diciendo a todos: ${ }^{52}$ «Por gracia de Dios yo, miserable, escapé de la peste de este flagelado, en la cual casi caí». ${ }^{33}$ Entonces, se reunieron todas las mujeres libradas del pecado a través del santo monje, llorando y proclamando a todos la verdad de su vida, afirmando por seguro que no lo habían visto dormir de costado, ni tocar una sola mano de una de ellas o beber vino ni una vez. ${ }^{54} \mathrm{Y}$ como todos las increpaban porque habían callado tantas virtudes del santo, se excusaban, en parte por su prohibición y mandato, en parte por el caso de la mujer golpeada por el Señor. ${ }^{55}$ Levantando, pues, el santo cuerpo y cargándolo hasta la iglesia, lo enterraron con gran honor. ${ }^{56}$ Así, el hombre aquel que había sido flagelado llevaba a cabo la celebración del beato monje con grandes gastos y limosnas. ${ }^{57}$ Finalmente, ingresando en su monasterio y viviendo en la misma celda de su maestro, terminó la vida en paz. ${ }^{8} \mathrm{Así}$, el santo patriarca daba gracias a Dios porque no había pecado contra el santo monje. ${ }^{59}$ Pero también, desde entonces, los ciudadanos de Alejandría comenzaron a abstenerse de los juicios de los hombres y de las infamias de los monjes. ${ }^{60}$ Así, Dios hizo muchos milagros a través de él después de su muerte.

[19] ¿QQué podría, pues, decirse exactamente sobre la humildad de este santo patriarca, cuando no sólo en la palabra, sino también en su manera de ser y actitud se presenta como el más humilde entre todos los demás? ${ }^{2} A s i ́$, sucedió una vez que fue visitado en la recámara patriarcal por un rico amigo suyo, de quien el santo patriarca solía recibir lo que quería para la obra de los pobres. 3 Y vista la humildad del lecho en el cual yacía y la humilde manta que lo cubría, al volver el rico aquel a su casa, le envió una manta bastante hermosa, diciendo: ${ }^{4}$ «Que tu santa paternidad reciba este pequeño presente y lo use por amor a mí como abrigo tuyo y de tu lecho, puesto que no es apropiado disminuir así el valor del dormitorio patriarcal». ${ }^{5}$ Tras recibir, pues, el presente, se cubrió con él una sola noche, pero, al desaprobarlo su consciencia, comenzó a discutir consigo mismo, diciendo: ${ }^{6}$ ¿¿Cuántos hermanos de Cristo se hielan por el frío, y de qué manera, rechinando los

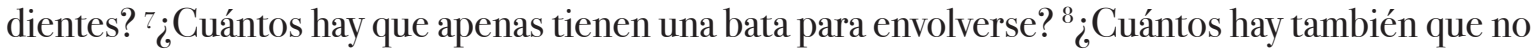
pueden extender los pies por la pequeñez del cobertor y de la manta? ${ }^{9} \mathrm{Y}$ tú, miserable Juan, yaces aquí envuelto por una preciosa manta, con la cual bien podrían cubrirse ciento cuarenta y cuatro hermanos de Cristo». ${ }^{\circ P}$ Pero decía esto porque la manta que le había sido enviada valía treinta y seis bizancios, cuando en la ciudad por un bizancio podían obtenerse cuatro cobijas. "'Y apenas

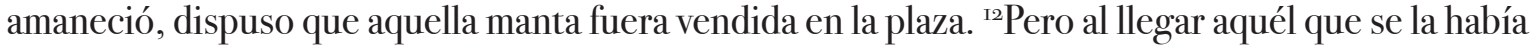
enviado, la compró él mismo y, luego de dar por ella treinta y seis bizancios, se la reenvió junto con el dinero, rogando muy firmemente que, luego de distribuir el dinero a los pobres, conservara en adelante aquella manta. ${ }^{\mathrm{I}} \mathrm{Y}$ tras llamarlo, dijo el patriarca: ${ }^{\mathrm{I}}{ }^{4}$ Ahora veremos quién prevalecerá: si yo vendiendo o tú volviendo a comprar». ${ }^{5}$ Comenzó a narrarle, entonces, cómo el beato Epifanio de Chipre, ${ }^{\mathrm{xx}}{ }^{\mathrm{al}}$ al ir como peregrino a Jerusalén y al ver en la mesa de Juan, patriarca de Jerusalén,

XXII. I Corintios $4 \cdot 5 \cdot$

XXIII. Epifanio fue obispo de Salamina en el siglo IV. El episodio en esta versión latina se encuentra más desarrollado

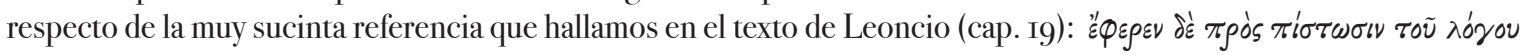


vasos de oro y plata, simuló que quería celebrar un convite. ${ }^{16} \mathrm{Y}$, tras recibir en préstamo dichos vasos del patriarca, los distribuyó todos entre los pobres de Jerusalén. ${ }^{17} \mathrm{Y}$ al reclamar luego el patriarca dichos vasos, le respondió Epifanio: ${ }^{18}$ «No es apropiado que un vicario de Cristo dé tan espléndidos banquetes y que los miembros de Cristos junto a él sean atormentados por el hambre. ${ }^{19}$ Por eso, atendí a tus pobres parroquianos y distribuí entre tus hijos lo que te sobraba». ${ }^{20}$ Luego de oír esto, el indignado patriarca, tras agarrar la vestimenta de San Epifanio, exclamó con arrogancia: ${ }^{21}$ «Así no me engañarás, sino que devolverás lo prestado». ${ }^{22}$ Entonces Epifanio respondió humildemente: ${ }^{23}$ «Que vea el Señor que sin causa extendiste tus manos temerarias hacia el obispo». ${ }^{24} \mathrm{Y}$ de inmediato se secó la mano del patriarca. ${ }^{25}$ Este, postrándose a los pies del santo, pidió perdón, y luego de que el santo obispo hiciera una oración por él, le fue restituida su mano y el patriarca antedicho no usó más tales cosas. ${ }^{26}$ De igual manera, le narró al mismo rico el ejemplo de un sirviente que había tenido antes en Chipre, que le decía: ${ }^{2}$ «Siempre que doy a los pobres alegre y abundantemente, también abunda lo tuyo, y cuando mezquinamente, también disminuye lo tuyo».

[20] 'Así, el beato patriarca solía convocar a aquellos que oía que acudían a las entrañas de la misericordia, preguntándoles cuidadosamente de dónde y de qué manera habían obtenido la misericordia, es decir, si de la naturaleza, como aquél que decía «desde la infancia creció conmigo la conmiseración», ${ }^{\text {XXV }}$ o si, más bien, de la doctrina y del consejo y ejemplo de otros. ${ }^{2}$ Pues los que tienen innata la conmiseración, como también aquellos que son fuertes por naturaleza en las otras virtudes, no consiguen tanta retribución frente a Dios, como los que, oponiéndose ellos mismos a la naturaleza con la razón, suelen compadecer y acudir a los necesitados por la buena doctrina y el ejercicio, puesto que dice el Salvador: ${ }^{3}$ El Reino de los cielos sufre la fuerza y los violentos lo arrebatan». ${ }^{x x v}{ }^{4}$ Entre otros, pues, el santo varón encontró a uno que le decía: ${ }^{5}$ «or mucho tiempo fui duro de corazón y no daba nada a los pobres. ${ }^{6}$ Un día, por cierto, al oír que la misericordia y sus obras eran recomendadas por sobre todo lo demás, volviéndome a mi corazón, comencé a ejercer violencia sobre mí mismo y, de inmediato, a entregar cada día al menos cinco cuadrantes a los pobres con los que me topaba. Pero, al abrir la mano para dar, me sobrevenía el pensamiento de que esto alcanzaba para comprar legumbres y vegetales y me parecía que sacaba esto de mi boca y de la de mis hijos y, por eso, no daba. ${ }^{8}$ Pero pensando que provocaría una gran ira de Dios en mi contra, si no cumplía lo que había prometido, ordené a mi administrador que, sin saberlo yo, entregara cada día de lo mío aquellos cinco cuadrantes. ${ }^{9}$ Él, cumpliendo esto por un tiempo, al observar que mis bienes en su mano aumentaban más y más de día en día, comenzó a dar, sin saberlo yo, todos los días diez cuadrantes. ${ }^{\text {Io }} \mathrm{Al}$ percatarse, pues, de que mis bienes evidentemente crecían por esta causa, abrió su mano y cada día, sin advertirlo yo hasta entonces, distribuyó de lo mío tres dracmas. "Pero pasado el tiempo, percibiendo también yo mismo tal abundancia e incremento de mis bienes, tras llamar al sirviente, le ordené que distribuyera diez cuadrantes, creyendo de verdad que hasta el momento había entregado sólo cinco. ${ }^{12} \mathrm{El}$ sirviente, oyendo esto y sonriendo, dijo: ${ }^{13}$ “En verdad confieso que soy ladrón, pero fiel. ${ }^{4}$ Pues me excedí en tu orden sobre lo tuyo, pero cambié para tu provecho, percibiendo que tus cosas aumentaban constantemente a causa de esto. ${ }^{5}$ Así pues,

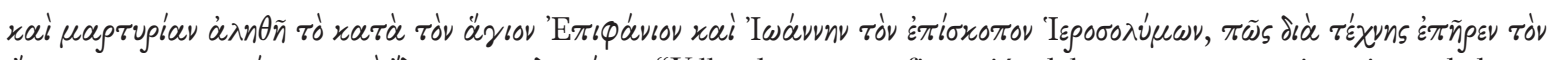

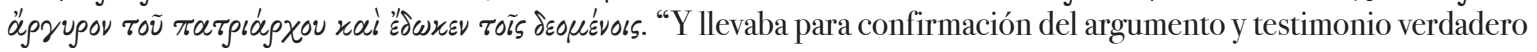
lo referente a san Epifanio y al Obispo Juan de Jerusalén, cómo por artificio levantó la plata del Patriarca y la dio a los necesitados" (Cavallero 294-295). La vida griega del santo (vid. BHG 596-6oI) y su traducción latina (BHL 2569) presentan varias divergencias respecto de la que leemos en el manuscrito arlatense, en especial en lo que relativo al castigo infligido al patriarca de Jerusalem, quien es cegado por Epifanio.

XхIV. Job 3 I. I8.

XXV. Mateo II.I2. 
confieso que distribuí por Dios abundantemente muchos de tus argénteos y áureos y siempre conseguí en esto que tus bienes se incrementaran". ${ }^{16}$ Por la habilidad, pues, de mi sirviente, llegué a la compasión y conmiseración de los pobres». ${ }^{17}$ Tras oír esto, pues, el santo patriarca se alegró y, dando gracias a Dios, confesó que apenas entonces había oído este hecho admirable y don de Dios entre los otros que había leído y oído.

[2I] 'Alrededor de la misma época, había en Alejandría dos clérigos, bastante vecinos, que vivían de la zapatería. ${ }^{2}$ Uno de ellos, el más experto en ese oficio, menos en ir a la iglesia, muy dedicado a su labor, apenas podía sustentarse sólo a sí mismo, aunque trabajaba también los domingos y días festivos, ávido de ganancia. ${ }^{3} \mathrm{El}$ otro, por cierto, menos experto en su oficio y más en los divinos, aunque casi todos los días se libraba de sus tareas e iba a la iglesia, no sólo se mantenía suficientemente a sí mismo con la tarea de este oficio, sino también a su padre y a su madre, con su propia mujer e hijos y abundaba más que su vecino en las cosas necesarias. ${ }^{4}$ Puesto que el otro había comenzado a envidiarlo, una vez le interrogó detenidamente de dónde le venía la abundancia de tantas cosas, cuando él mismo pasaba necesidad, aunque trabajaba asiduamente, siendo también más experto y más dedicado a su labor. ${ }^{5}$ Su vecino, que quería impulsarlo a ir a la iglesia, le respondió así: ${ }^{6}$ ¿queridísimo hermano, tampoco yo podía a veces mantenerme a mí mismo, pero después de que, convertido a Dios, comencé a ir a la iglesia, encontré bastante en este camino para mí y para los míos. ㄱAhora, por lo tanto, si quieres, sigue mis planes de que vengas cada día conmigo a la iglesia y dividamos equitativamente entre nosotros lo que encontremos». ${ }^{8} \mathrm{Al}$ venir, pues, aquél y acompañar a su colega a la iglesia, comenzaron a acrecentarse claramente sus bienes y a abundar más de día en día. ${ }^{9} \mathrm{Y}$ como refiriera esto, dando gracias a Dios y a su socio, le dijo su socio: ${ }^{\mathrm{I}}{ }$ Por cierto, hermano, has de saber que en este camino nunca encontré nada, salvo que aprendí el incremento de mi providencia por Dios. "Y siempre me repetí aquello del Evangelio "busquen primero el Reino de Dios y todas estas cosas les serán añadidas”». xxv I2 Así, luego de que la noticia de este hecho llegó al santo varón, tras llamar a aquél que había impulsado a su vecino a tanto bien, lo incorporó a los ministros de la iglesia patriarcal y además ordenó presbítero al que, con el paso del tiempo, progresaba para mejor.

[22] 'También dispuso el Señor tentar a su siervo y probarlo de este modo. ${ }^{2} \mathrm{Al}$ irrumpir, pues, la guerra y la fuerza de los bárbaros en las regiones vecinas, una multitud de fieles pobres tan grande descendió a Alejandría para limosnas y sustento del varón de Dios que se gastaban en las acciones piadosas para aquellos todo lo que él tenía a disposición en los tesoros de la iglesia, tanto las riquezas en oro y plata, así como en trigo. ${ }^{3} \mathrm{~A}$ esto también se sumó la fuerte hambruna que oprimió terriblemente a todo Egipto, puesto que la habitual corriente del Nilo había descendido ese año más de lo normal. «Puesto que concurrían no sólo los extranjeros, sino que también acudían a él los autóctonos, apenas alcanzaba el alimento del varón de Dios. ${ }^{5} \mathrm{Al}$ acabarse, pues, lo que él tenía, comenzó a mendigar de otros para la multitud de pobres. ${ }^{6} \mathrm{Y}$ como lo que otros le daban no era suficiente, comenzó a tomar prestado de los ricos. ₹En verdad, como ya había recibido en préstamo diez talentos de oro, llamados comúnmente quinarios, y no hallaba otro préstamo, temiendo todos enfermarse por el hambre, comenzó a entristecerse y a pensar qué haría, derramando oraciones a Dios. ${ }^{8}$ Pero había entonces en la ciudad un rico letrado, que desde tiempo atrás quería ser hecho clérigo y nombrado entre los ministros de la iglesia, pero no podía porque lo prohibía el derecho, ya que, muerta su primera mujer y casado luego con otra, había contraído matrimonio dos veces. ${ }^{9}$ Así pues, este, habiendo oído acerca de la estrechez del santo varón, pensó que con su dinero lo 


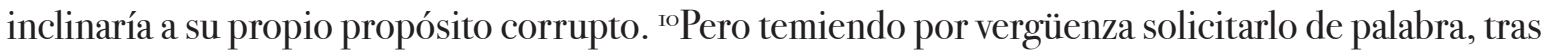
escribir y mandar una carta a través de su hijo, prometió que le daría inmediatamente doscientos modios de grano con ciento ochenta rotas de oro en alimento para los pobres, si, disponiéndolo él, lo elevaba y lo admitía con sus demás diáconos en la asamblea y en la función de los diáconos. "Aducía, por consiguiente, que frecuentemente la necesidad suprime una ley. ${ }^{\mathrm{I} 2} L e i ́ d a$, pues, la carta por el varón de Dios, lo convocó, diciéndole en privado: ${ }^{13}$ «Aceptaríamos por necesidad tu ofrenda para los pobres, si fuera inmaculada, pues ordena el Señor que todo sacrificio se ofrezca inmaculado. Así, en efecto, el Señor quiere que le sea presentada una Iglesia gloriosa, que no tenga ni arruga ni mancha». ${ }^{\text {xvI I }}{ }^{4} Y$ agregó: ${ }^{15}$ «¿Acaso nos es lícito cambiar o corromper los estatutos de la santa Iglesia a causa de tus donaciones? ${ }^{16}$ ¿Será que no ejercitas aquel antiguo dicho apostólico para el que ofrece su dinero a Dios a cambio del don celestial? ${ }^{17 "}$ Que tu dinero $D$ dice $\mathrm{C}$ perezca contigo, puesto que pensaste que el don de Dios se poseía con dinero. ${ }^{18}$ En efecto, no tienes parte ni suerte en esta discusión. ${ }^{19} \mathrm{Tu}$ corazón, en efecto, no es recto frente a Dios" ${ }^{\mathrm{x} v \mathrm{II}}{ }^{20}$ ¿Acaso consideras que la mano del Omnipotente es débil como para no poder proveer a sus pobres? ¿ ¿Y quien sació con unos pocos panes a muchos miles de hombres, no podrá multiplicar para nosotros estos diez modios restantes de trigo?» ${ }^{22}$ Tras oír esto, aquel ambicioso se alejó del santo varón con vergüenza y turbación. ${ }^{23} \mathrm{Y}$ de inmediato, entró alguien, que anunciaba con alegría que dos naves de la iglesia y del santo patriarca, cargadas de trigo, habían llegado desde Satalia y Grecia ${ }^{x x i x}$ y entrado al puerto. ${ }^{24}$ Entonces dijo el santo: ${ }^{25}$ «Feliz quien confía en el Señor, temiéndole y observando sus mandatos». ${ }^{26}$ Y dio gracias a Dios, que conservó a su siervo limpio de la depravación simoníaca.

[23] 'Para anunciar la virtud de la limosna y para invitar a otros a la obra de misericordia, el hombre de Dios refería con gusto el milagro que una vez le había ocurrido a un chipriota de este modo: ${ }^{2} \ll \mathrm{Al}$ irrumpir los bárbaros en Chipre, sucedió que unos chipriotas fueron conducidos a Persia como prisioneros y transferidos a una cárcel espantosa. ${ }^{3} \mathrm{Con}$ el paso del tiempo, por cierto, fallecidos algunos y otros rescatados y liberados, uno de ellos se quedó en prisión. ${ }^{4} \mathrm{Al}$ regresar, pues, a su tierra algunos de sus vecinos, los padres de este comenzaron a preguntar ansiosamente acerca del que se había quedado. ${ }^{5}$ Los que habían vuelto liberados, les dijeron que ellos lo habían sepultado con sus propias manos y creían que así era. ${ }^{6}$ Entonces, los padres, tras averiguar y anotar el día de su muerte, comenzaron a dar cada año en determinados días limosnas a los pobres para el descanso de su alma. 'Este, pues, luego de cuatro años, con el auxilio de Dios, tras ser liberado de prisión y al regresar junto a los suyos, fue recibido con gozo y honor ante la admiración de todos. ${ }^{8} \mathrm{Y}$ al contarle que, teniéndolo por muerto, daban limosnas por él en días establecidos, les preguntó cuáles días hacían esto. ${ }^{9}$ Estos dijeron: ${ }^{\text {I0 }}$ Tres días al año, obviamente el día de la santa Pascua y de Pentecostés y del Bautismo del Señor". "Luego de anotarlos con precisión, les afirmó que en estos días un honorable varón, vestido de blanco, iba hacia él en la cárcel y, soltándole las cadenas, lo conducía afuera para pasear todo el día. ${ }^{\text {I2} P e r o ~ a l ~ d i ́ a ~ o ~ a ~ l a ~ n o c h e ~ s i g u i e n t e, ~ d e v o l v i e ́ n d o l o ~ a ~ l a ~ c a ́ r c e l, ~}$ lo ataba con las cadenas». ${ }^{13}$ Así pues, del ejemplo de este, el varón de Dios deducía cuán magnífico es repartir limosnas a los pobres, las cuales no sólo sirven para consuelo y paz de los vivos, sino también para indulgencia y salvación de los muertos.

XXVII. Efesios 5. 27.

XXVIII. Hechos 8.20.

XXIX. En las versiones griegas y en las traducciones latinas de Anastasio y la anónima amalfitana se lee unánimemente 'Sicilia' sin que se consignen variantes. 
[24] 'Pero para que nadie, por azar, disponga y desee de inmediato el fruto de sus propias limosnas, el varón de Dios expuso alguna vez sobre este signo acordado por el Señor. ${ }^{2} P u e s$ cuando, cierta vez, un rico alejandrino, al ver que una gran multitud acudía al santo patriarca y vertía abundantemente de sus propios bienes a los tesoros de la Iglesia para el sustento de los pobres, vino también él mismo, ofreciendo siete rotas y media de oro, mientras suplicaba que rogara a Dios por la salvación de su único hijo y recondujera al puerto su nave, que previamente había enviado a África. ${ }^{3}$ Afirmaba, además, que no había conservado para sí nada de oro en su casa. «Recibida, pues, la donación y colocada en los tesoros de la iglesia debajo del altar, el santo varón comenzó a orar por él y los suyos, a fin de que Dios omnipotente les concediera que supiese conducir a la salvación de sus almas. ${ }^{5}$ Sucedió, pues, que a los treinta días murió el único hijo del rico mencionado y, al tercer día, vio venir su nave. ${ }^{6}$ Pero al tener que entrar al puerto, luego de chocar, desapareció repentinamente. ?Pero por gracia de Dios, aunque las mercancías se hundieron en las profundidades, los hombres escaparon con un leño. ${ }^{8}$ Así pues, sumada una desgracia a otra desgracia, aquel hombre sufrió demasiado. ${ }^{9}$ Relatado igualmente esto al patriarca, se compadeció también él mismo del hombre

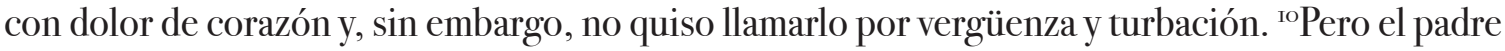
de las misericordias y Dios dador de todo consuelo no quiso defraudar al hombre por su esperanza y por la fe que había tenido en el santo varón. "Una noche, pues, se le apareció en sueños un hombre con el aspecto y la vestimenta del patriarca, que le decía: ${ }^{12}$ ¿¿Por qué, hermano, sufres tanto por la muerte de tu hijo, que fue llevado a la gloria? ${ }^{13} Y$ si hubiese vivido, habría perecido tras ingresar al camino del mundo. ${ }^{14}$ ¿Acaso no me rogaste que intercediera por su salvación? ${ }^{15}$ ¿Y por qué sufres por la nave? ${ }^{16} \mathrm{El}$ Señor, en efecto, te arrebató aquellas cosas que alguna vez te habrían dañado. ${ }^{17}$ ¿Acaso no te manifestó su misericordia el que no concedió que las almas de los hombres perecieran con un patrimonio inútil?». ${ }^{18}$ Tras oír estas cosas, el hombre, luego de despertarse y levantarse admirablemente consolado, se acercó al santo para contarle todo lo que había visto en orden y así, reconfortándose mutuamente uno y otro, dieron gracias al Altísimo.

[25] 'Después de esto, sucedió que un varón extranjero, que había oído acerca de la generosidad del varón de Dios, quiso probarla y, vistiendo pobremente, encontró al santo varón que iba a su hospital, según su costumbre, tres veces a la semana. ${ }^{2} Y$ tras pedirle limosna, el santo varón ordenó a su tesorero que le diera seis áureos. ${ }^{3}$ Y marchándose, el varón aquel cambió la vestimenta y encontrando de nuevo al varón de Dios, le pidió limosna. ${ }^{4}$ Y ordenó que le dieran seis áureos por segunda vez. ${ }^{5} \mathrm{Y}$ al decirle el tesorero: ${ }^{6}$ «Ten más cuidado. ${ }^{7}$ Este es el mismo al cual le diste otros seis áureos», el varón de Dios simuló que no lo había oído. ${ }^{8}$ Por eso, por tercera vez lo encontró el varón aquel, con la vestimenta cambiada, pidiendo como antes. ${ }^{9}$ Entonces el tesorero, apartando un poco a su señor, le dice en privado: ${ }^{\mathrm{I0}}$ «Atención, aquel embustero regresa por tercera vez». "Pero exclamando en voz alta, dijo el santo varón: ${ }^{12}$ «Ahora, por tercera vez, dale doce áureos, puesto que tal vez es Cristo, que me tienta». ${ }^{13}$ Así pues, se alejó el varón aquel, habiendo sido probada la paciencia y el desprendimiento del santísimo patriarca.

[26] 'Así, otro día, cuando el beato patriarca salía para conmemorar un martirio en una iglesia fuera de la ciudad, ${ }^{\mathrm{xxx}}$ encontró en el camino a una mujer que le pedía un favor. ${ }^{2}$ Pero al decirle sus sirvientes que aguardara hasta su vuelta, los increpó, diciendo: ${ }^{3}$ ¿¿Cómo oirá el Señor nuestras oraciones, si postergamos dar al que está necesitado?» 4Por eso, no quiso mover un pie de ese lugar, hasta dar satisfacción a la mujer.

Xxx. En el texto griego se indica que Juan se dirigía al santuario de los santos Ciro y Juan. Vid. n. XIX. 
[27] 'En aquellos días había en la ciudad de Alejandría un joven de buen natural, que tenía un padre que trabajaba muchísimo. ${ }^{2}$ Este, mientras hacía el testamento de sus bienes, dijo a su hijo: ${ }^{3}$ ¿Qué prefieres de estas dos cosas, es decir, o bien debería legarte a ti la diez rotas que tengo, o bien a la gloriosa virgen santa María?» ${ }^{4}$ Este respondió: ${ }^{5}$ «Dalas mejor a la santa Virgen». ${ }^{6}$ Entonces, su padre ordenó que las distribuyeran entre los pobres en honor de la santa Virgen. 7Pero cuando murió el padre, el hijo comenzó a pasar necesidad. ${ }^{8}$ No obstante, pese a ello, iba devotamente día y noche a la iglesia y a la memoria de la virgen María. ${ }^{9}$ Mas le avergonzaba mendigar y pedir ayuda

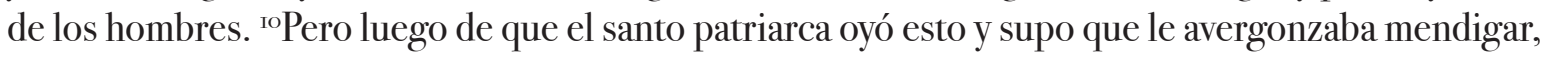
llamó a uno que era honesto, diciéndole: "«Escribe en una hoja vieja que dicho joven es pariente del señor patriarca. ${ }^{12} Y$ como si la hubieses encontrado junto a ti, le dices: ${ }^{13 \text { “" }}$ ¿Cómo es esto de que tú eres pobre, si eres pariente de tan gran varón que no permite a nadie que acude a él pasar necesidad? ${ }^{14}$ Pues hallé en mis cartas que tú eres familiar de él. ${ }^{55}$ Si te avergüenzas de hablarlo con él, yo intercederé por ti ante el mismo" $» .{ }^{16} \mathrm{El}$ joven a él: ${ }^{17} \ll$ Ve, intenta y vuelve a contarme». ${ }^{18} \mathrm{Al}$ regresar, pues, el varón aquel de lo del santo patriarca, le narró al joven su respuesta, diciendo: ${ }^{19}$ «Así me respondió el hombre de Dios: ${ }^{20 " S e ́, ~ p o r ~ c i e r t o, ~ q u e ~ t e n g o ~ u n ~ p a r i e n t e ~ q u e ~ n o ~ c o n o c i ́ ~ d e ~}$ rostro. ${ }^{21 P e r o ~ v e ~ y ~ t r a ́ e l o ~ h a c i a ~ m i ́ ~ c o n ~ t u ~ c a r t a " » . ~}{ }^{22}$ Llevado, pues, el joven hasta el santo patriarca, el beato varón lo abrazó, diciendo: ${ }^{23}$ «Bienvenido, queridísimo pariente». ${ }^{24} \mathrm{Y}$ de inmediato, luego de darle abundantes regalos, le dio en matrimonio a la hija de un gran ciudadano de Alejandría, rico y poderoso. ${ }^{25}$ Así pues, hizo que el joven comprobara que no puso su esperanza en Dios porque estaba confundido, pero sobre todas las cosas aventajó en ocupar su pensamiento en el Señor.

[28] 'En aquel tiempo, había en la zona de Alejandría un varón que tenía un casal muy bueno, pero no había producido para su dueño el fruto habitual a causa de la sequía y de la escasez. ${ }^{\mathrm{xxx}}{ }^{2} Y$ al ser agobiado por aquellos que se encargaban de los impuestos reales para que devolviera la tasa debida al rey y no tener de dónde sacarla, se dirigió a un rico amigo suyo para pedirle un préstamo. ${ }^{3 P e r o}$ el rico aquel postergaba el préstamo de día en día. `Él, sin embargo, urgido por la exigencia de los impuestos reales, declaró su situación al santo patriarca. ${ }^{5}$ Este, compadeciéndose en gran manera del que estaba agobiado, le concedió de inmediato lo que pedía. ${ }^{6}$ La noche siguiente, por cierto, el rico antedicho tuvo en sueños una visión admirable. 'Le parecía como que estaba en la iglesia entre los que llevaban ofrendas al altar, de los cuales cada uno de los oferentes recibía de inmediato el céntuplo de parte de Dios. ${ }^{8}$ Mas uno, acercándose al rico, le presentaba un pan, diciendo: ${ }^{9}$ «Recibe

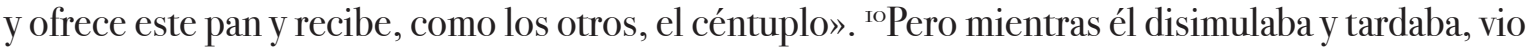
al santo patriarca que recibía el pan y lo ofrecía y recibía el céntuplo. "Pero al despertarse y advertir en parte la visión, hizo llamar al que había pedido el préstamo, diciéndole: ${ }^{12}$ ¿Quieres recibir lo que pediste?». ${ }^{13}$ Este respondió: ${ }^{14}$ «No lo necesito, puesto que el señor patriarca se anticipó y me dio lo que te pedí, puesto que lo postergaste demasiado». ${ }^{15} \mathrm{El}$ rico a él: ${ }^{16}$ «Dijiste bien, ya que el patriarca me arrebató lo mío a causa de mi propia inercia. ${ }^{17} \mathrm{Y}$ merecidamente, ya que ay de aquél que dice a su amigo "ve y regresa de nuevo, mañana te daré, aunque te podría dar de inmediato"». exponiéndole su visión en orden, hizo penitencia por su propia indiferencia. ${ }^{19} \mathrm{Y}$ glorificaban a Dios, que es justo y misericordioso en todos sus caminos. ${ }^{2 \circ} \mathrm{Y}$ con estas cosas y de este modo es evidente, pues, cuán misericordioso y generoso en dar fue el beato varón.

XXXI. En la versión griega se indica que es producto de la sequía del río Nilo, a la que se alude también en el capítulo 22 de este texto, correspondiente al in de la griega.

XXXII. Proverbios 3. 28. 
[29] 'Pero también se mostró verdaderamente misericordioso en perdonar. 'Una vez, en efecto, sucedió que dos de sus clérigos riñeron entre sí. Por esta causa, expulsó a ambos de la iglesia. ${ }^{3}$ Uno de ellos, reconociendo su falta, hizo penitencia y, tras pedir perdón, alcanzó la reconciliación. 4Pero el otro más bien se alegraba de haber sido expulsado para vagabundear más libremente hacia lo vano e inútil. 5Pero también maquinaba maliciosamente cómo provocar la ira del santo, así que muchos creían que él mismo había proyectado el antedicho robo al patricio. ${ }^{\text {xxII }}{ }^{6}$ Por lo tanto, cuando supo que no se corregía con la sentencia de suspensión, sino que más bien emperoraba, lo convocó para que volviera a la iglesia por medio del buen trato y las santas advertencias. ?En efecto, el santo varón ejercitaba aquello del Apóstol «¿quién se debilita y yo no me debilito? »xxiv y aquello «nosotros, los más fuertes, debemos soportar las flaquezas de los débiles y no complacernos a nosotros mismos». ${ }^{\text {xxv }}{ }^{8}$ Pero no pudo hacerlo volver. ${ }^{\text {Xxx }}$

XXXIII. Remite al capítulo en el que aparece el patricio Nicetas, el 9 de esta versión latina y io en la versión griega larga.

XXXIV. II Corintios II. 29.

XXXV. Romanos I5. I.

XXXVI. El texto queda trunco. La versión larga griega (capítulo I2) desarrolla la manera en la que Juan, mostrándose humilde y no rencoroso, logra finalmente que el clérigo se arrepienta de sus faltas y fuese nuevamente digno de ser ordenado. 


\section{Obras citadas}

AASS. I863. Acta Sanctorum, III, Januarï (Parisiis: Victor Palmé)

BHL. I898-I899. Bibliotheca hagiographica latina antiquae et mediae aetatis, I, A-I (Bruxelles: Socii Bollandiani)

Bohdziewicz, Olga Soledad. 20I9. 'Una contribución al estudio de una traducción latina poco conocida: la Vida de Juan el Limosnero [BHL 4392]', Mirabilia, 28: 459-477 < https:/ /go.uv.es/ $\underline{\mathrm{fLVvm8g}>}$

Cavallero, Pablo; Ubierna, Pablo; Capboscq, Alberto et al. (ed.). 2OII. Leoncio de Neápolis Vida de Juan el Limosnero (Buenos Aires: Facultad de Filosofía y Letras Universidad de Buenos Aires)

Chiesa, Paolo (ed.). 1995. Vita e morte di Giovanni Calibita e Giovanni l'Elemosiniere: due testi 'amalfitani' inediti (Cava dei Tirreni: Avagliano Editore)

Chiesa, Paolo; Cupiccia, Matilde; Galli, Adele. 2005. 'Anastasius Bibliothecarius', in La trasmissione dei testi latini del Medioevo, ed. by Paolo Chiesa and Lucia Castaldi, Te.Tra, 2 (Firenze: SISMEL-Edizioni del Galluzzo), pp. 87-IO3

Déroche, Vincent. 1995. Études sur Léontios de Néapolis (Uppsala: Uppsala Universitet)

Dolbeau, François. I980. 'Anciens Possesseurs des manuscrits hagiographiques latins conservés à la Bibliothèque nationale de Paris', Revue d'Histoire des Textes, 9: I83-238 < $\underline{\text { https: / /go.uv.es/ }}$ qj6Veaj>

Festugière, André-Jean; Ryden, Lennart (ed.). 1974. Léontios de Néapolis Vie de Syméon le Fou et Vie de Jean de Chypre (Paris: Librairie orientaliste Paul Geuthner)

Fros, Henricus. 1986. Bibliotheca hagiographica latina antiquae et mediae aetatis: Novum supplementum (Bruxelles: Socii Bollandiani)

Gelzer, Heinrich (ed.). I893. Leontios'von Neapolis Leben des heiligen Johannes des Barmherzigen Erzbischofs von Alexandrien (Freiburg; Leipzig: Mohr) < https://archive.org/details/ leontiosvonneapoogelzgoog $>$

Martindale, J. R. 1992. The Prosography of the Later Roman Empire (Cambridge: Cambridge University Press)

Rapp, Claudia. 2004. 'All in the Family: John the Almsgiver, Nicetas and Heraclius', Nea Rhome r: I2I-I34

Rosweyde, Heribert (ed.). I6r5. Vitae Patrum: De vita et verbis seniorum libri X (Antwerpen: Ex officina Plantiniana)

Thomas, Marcel (ed.). I988. Catalogue général des manuscrits latins, VII, $N^{5 s} 3776$ à 3835 : Homéliaires (Paris: Bibliothèque nationale France)

Venturini, Guido (ed.). 2020. La versione siriaca della Vita di Giovanni il Misericordioso di Leonzio di Neapolis (Lovanii: In aedibus Peeters) 


\section{Apéndice: Correspondencias de los capítulos}

Se expresa con asterisco (*) la posible relación con el capítulo indicado. Los números entre corchetes en la versión griega larga corresponden a la capitulación establecida por Festugière (I974).

\begin{tabular}{|c|c|c|c|c|}
\hline $\begin{array}{l}\text { Traducción la- } \\
\text { tina arlatense }\end{array}$ & Versión griega larga & $\begin{array}{l}\text { Versiones griegas } \\
\text { media y breve }\end{array}$ & $\begin{array}{c}\text { Traducción latina de } \\
\text { Anastasio Bibliote- } \\
\text { cario }\end{array}$ & $\begin{array}{l}\text { Traducción latina } \\
\text { amalfitana }\end{array}$ \\
\hline I & - & & - & - \\
\hline 2 & 6 & VII-VIII & VI-VII & - \\
\hline 3 & $\begin{array}{c}{ }^{*} \mathrm{I} 6 \\
* 44[46] \\
\end{array}$ & $\begin{array}{l}{ }^{*} \mathrm{XVIII} \\
{ }^{*} \mathrm{XLII} \\
\end{array}$ & $\begin{array}{l}{ }^{*} \mathrm{XVII} \\
{ }^{*} \mathrm{XLII} \\
\end{array}$ & - \\
\hline 4 & $43[45]$ & XLII & XLI & - \\
\hline 5 & $4-5$ & $\mathrm{~V}-\mathrm{VI}$ & $\mathrm{V}$ & $\mathrm{V}-\mathrm{VI}$ \\
\hline 6 & 2 & III & III & III \\
\hline 7 & 3 & IV & IV & IV \\
\hline 8 & $\mathrm{I}$ & II & II & II \\
\hline 9 & IO & XII & $\mathrm{XI}$ & XII \\
\hline IO & 9 & $\mathrm{XI}$ & $\mathrm{X}$ & $\mathrm{XI}$ \\
\hline II & 6 & VII-VIII & VI-VII & VII-VIII \\
\hline I2 & 8 & $X$ & IX & $X$ \\
\hline $\mathrm{I} 3$ & $26[27]$ & XXVII & XXVI & - \\
\hline I4 & I8 & $\mathrm{XX}$ & XIX & - \\
\hline $\mathrm{I} 5$ & $2 \mathrm{I}$ & XXII & XXI & - \\
\hline I6 & 22 & XXIII & XXII & - \\
\hline $\mathrm{I} 7$ & 23 & XXIV & XXIII & XXIV \\
\hline I8 & 37 [38] & XXXVI & XXXV & XXVI \\
\hline I9 & I9 & XXI & $\mathrm{XX}$ & - \\
\hline 20 & $39[40]$ & XXXVIII & XXXVII & - \\
\hline $2 \mathrm{I}$ & $49\left[5^{\mathrm{I}}\right]$ & XLIVa & XLVII & XLIV \\
\hline 22 & II & XIII & XII & XIII \\
\hline 23 & 24 & $\mathrm{XXV}$ & XXIV & - \\
\hline 24 & 25 & XXVI & $\mathrm{XXV}$ & - \\
\hline 25 & 7 & IX & VIII & IX \\
\hline 26 & $3 \mathrm{O}[3 \mathrm{I}]$ & XXXI & $\mathrm{XXX}$ & - \\
\hline 27 & $34[35]$ & XXXIV & XXXIII & - \\
\hline 28 & $29[3 \mathrm{O}]$ & XXX & XXIX & - \\
\hline 29 & I2 & XIV & XIII & XIV \\
\hline
\end{tabular}

